Article

\title{
New Data on the Isomorphism in Eudialyte-Group Minerals. 1. Crystal Chemistry of Eudialyte-Group Members with Na Incorporated into the Framework as a Marker of Hyperagpaitic Conditions
}

\author{
Ramiza K. Rastsvetaeva ${ }^{1}$, Nikita V. Chukanov ${ }^{2,3, *}$, Igor V. Pekov ${ }^{3,4}$, Christof Schäfer ${ }^{5}$ and \\ Konstantin V. Van ${ }^{6}$ \\ 1 Shubnikov Institute of Crystallography of Federal Scientific Research Centre "Crystallography and \\ Photonics" of Russian Academy of Sciences, 119333 Moscow, Russia; rast.crys@gmail.com \\ 2 Institute of Problems of Chemical Physics, Russian Academy of Sciences, Chernogolovka, \\ 142432 Moscow, Russia \\ 3 Faculty of Geology, Moscow State University, 119991 Moscow, Russia; igorpekov@mail.ru \\ 4 Vernadsky Institute of Geochemistry and Analytical Chemistry, Russian Academy of Sciences, \\ 119991 Moscow, Russia \\ 5 Independent researcher, Gustav Stresemann-Strasse 34, 74257 Untereisesheim, Germany; \\ mspech612@gmail.com \\ 6 Institute of Experimental Mineralogy, Russian Academy of Sciences, 142432 Moscow, Russia; kvv@iem.ac.ru \\ * Correspondence: nikchukanov@yandex.ru
}

Received: 5 June 2020; Accepted: 26 June 2020; Published: 29 June 2020

check for updates

\begin{abstract}
A review of the crystal chemistry of Fe-deficient eudialyte-group minerals is given Specific features of cation distribution over key sites in the crystal structure, including partial substitution of $\mathrm{Fe}^{2+}$ with $\mathrm{Na}, \mathrm{Mn}$ and $\mathrm{Zr}$ at the $\mathrm{M} 2$ site are discussed. It is concluded that Na-dominant (at the $M 2$ site) eudialyte-group members ( ${ }^{M 2} \mathrm{Na}$-EGMs) are markers of specific kinds of specific peralkaline (hyperagpaitic) igneous rocks and pegmatites. New data are obtained on the chemical composition, IR spectra and crystal chemistry for two samples of ${ }^{M 2} \mathrm{Na}$-EGMs with disordered $M 1$ cations, which are a potentially new mineral species with the simplified formula $\left(\mathrm{Na}, \mathrm{H}_{2} \mathrm{O}\right)_{15} \mathrm{Ca}_{6} \mathrm{Zr}_{3}\left[\mathrm{Na}_{2}(\mathrm{Fe}, \mathrm{Zr})\right]\left[\mathrm{Si}_{26} \mathrm{O}_{72}\right](\mathrm{OH})_{2} \mathrm{Cl} \cdot n \mathrm{H}_{2} \mathrm{O}$.
\end{abstract}

Keywords: mineral; eudialyte group; crystal structure; isomorphism; infrared spectroscopy; $M 2$ key site; peralkaline rock; Lovozero alkaline complex; Ilímaussaq alkaline complex

\section{Introduction}

Eudialyte, ideally $\mathrm{Na}_{15} \mathrm{Ca}_{6} \mathrm{Fe}^{2+}{ }_{3} \mathrm{Zr}_{3}\left(\mathrm{Si}_{26} \mathrm{O}_{73}\right)\left(\mathrm{O}, \mathrm{OH}, \mathrm{H}_{2} \mathrm{O}\right)_{3}(\mathrm{Cl}, \mathrm{OH})_{2}(\mathrm{Z}=3)$, is the most important zirconosilicate mineral. It was discovered two hundred years ago in the Ilímaussaq alkaline complex, South Greenland [1], and later, numerous other finds of eudialyte and related mineral species defined as eudialyte-group members were described. Eudialyte-bearing rocks are considered as a potential source of different rare elements ( $\mathrm{Zr}, \mathrm{Hf}, \mathrm{Nb}, \mathrm{Y}$, lanthanides, etc.); the largest reserves of such rocks with potential industrial significance are in the Lovozero alkaline complex, Kola Peninsula, Russia, and in the Ilímaussaq complex.

The crystal structures of eudialyte-group minerals (EGMs, Figure 1) are based on a heteropolyhedral framework $\left\{\mathrm{M1}_{6} \mathrm{M}_{3} \mathrm{Z}_{3}\left[\mathrm{Si}_{3} \mathrm{O}_{9}\right]_{2}\left[\mathrm{Si}_{9} \mathrm{O}_{27}\right]_{2}\right\}$ consisting of 9- and 3-membered rings of tetrahedra $\left(\mathrm{Si}_{9} \mathrm{O}_{27}\right.$, $\left.\mathrm{Si}_{3} \mathrm{O}_{9}\right)$ and 6-membered rings of octahedra $\mathrm{M1}_{6} \mathrm{O}_{24}\left(\mathrm{M} 1=\mathrm{Ca}, \mathrm{Mn}^{2+}, \mathrm{Fe}^{2+}, \mathrm{Na}, \mathrm{Ln}\right.$, Sr where $\mathrm{Ln}$ are lanthanides), linked via isolated $\mathrm{ZO}_{6}$ octahedra $\left(\mathrm{Z}=\mathrm{Zr}\right.$, Ti) and ${ }^{[4-7]} \mathrm{M}_{2} \mathrm{O}_{n}$ polyhedra $\left(\mathrm{M} 2=\mathrm{Fe}^{2+}, \mathrm{Fe}^{3+}\right.$, $\mathrm{Mn}^{2+}, \mathrm{Na}$, $\mathrm{Zr}$, etc.; coordination numbers are indicated in square brackets). Additional sites ( $M 3$ and 
M4) located at the centers of the $\mathrm{Si}_{9} \mathrm{O}_{27}$ rings are occupied by ${ }^{[4]} \mathrm{Si},{ }^{[6]} \mathrm{Nb}$, rarely ${ }^{[6]} \mathrm{W}$, and some other components, and can be partly vacant. Actually, the key sites $M 2, M 3$ and $M 4$ are microregions, each of which can contain several close-spaced sites with different coordinations. For eudialyte sensu stricto, the formula of the framework is $\left\{\mathrm{Ca}_{6} \mathrm{Fe}^{2+}{ }_{3} \mathrm{Zr}_{3}\left[\mathrm{Si}_{3} \mathrm{O}_{9}\right]_{2}\left[\mathrm{Si}_{9} \mathrm{O}_{27}\right]_{2}\right\}^{18-}$.

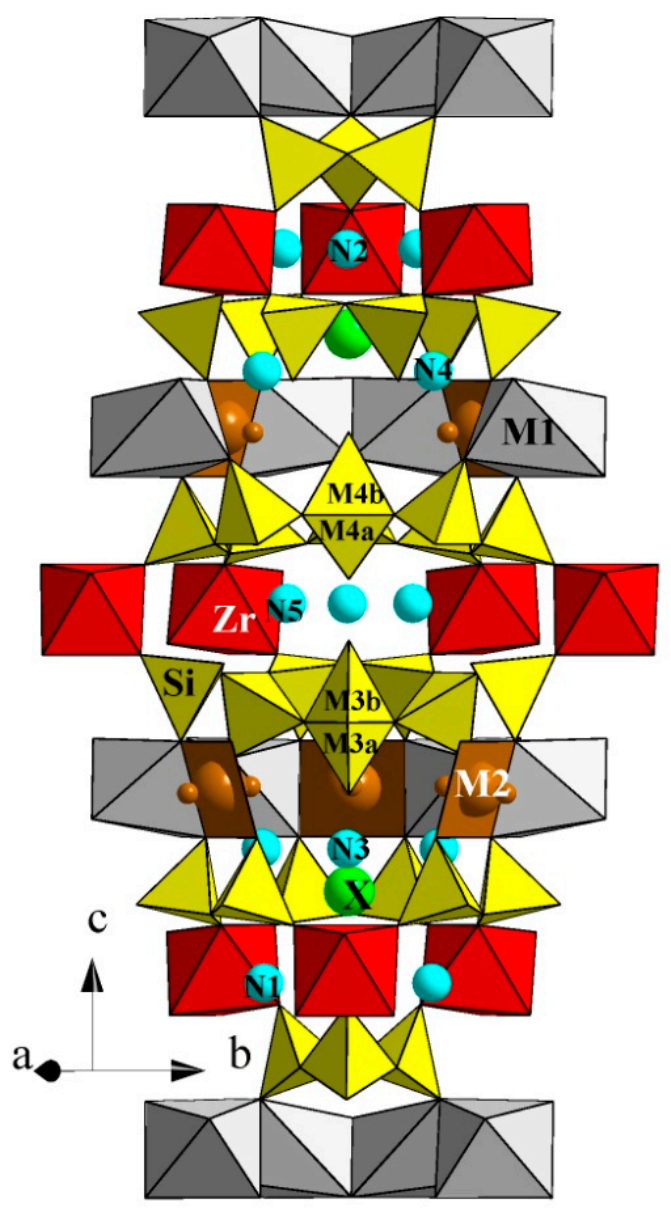

Figure 1. The crystal structure of eudialyte-group minerals (a simplified sketch).

Different schemes of homovalent, heterovalent and blocky isomorphism can occur in eudialyte-type structures, which results in the unique crystal-chemical diversity of eudialyte and related minerals. At present, the eudialyte group includes 29 recognized mineral species [2-8]. During the last five years, a lot of new data on the crystal chemistry and properties of these minerals have been published [9-31], and three new mineral species belonging to the eudialyte group have been discovered: ilyukhinite $\left(\mathrm{H}_{3} \mathrm{O}, \mathrm{Na}\right)_{14} \mathrm{Ca}_{6} \mathrm{Mn}^{2+}{ }_{2} \mathrm{Zr}_{3} \mathrm{Si}_{26} \mathrm{O}_{72}(\mathrm{OH})_{2} \cdot 3 \mathrm{H}_{2} \mathrm{O}$ [11], siudaite $\mathrm{Na}_{8} \mathrm{Mn}^{2+}{ }_{3} \mathrm{Ca}_{6}\left(\mathrm{Fe}^{3+}, \mathrm{Mn}^{2+}\right)_{3} \mathrm{Zr}_{3} \mathrm{NbSi}_{24}$ $(\mathrm{Si}, \square, \mathrm{Ti}) \mathrm{O}_{72}(\mathrm{O}, \mathrm{OH})_{3} \mathrm{Cl} \cdot 4 \mathrm{H}_{2} \mathrm{O}[19]$ and sergevanite $\mathrm{Na}_{15}\left(\mathrm{Ca}_{3} \mathrm{Mn}^{2+}{ }_{3}\right)\left(\mathrm{Na}_{2} \mathrm{Fe}^{2+}\right) \mathrm{Zr}_{3} \mathrm{Si}_{26} \mathrm{O}_{72}(\mathrm{OH})_{3} \cdot \mathrm{H}_{2} \mathrm{O}$ (IMA 2019-057). Simplified crystal chemical formulae of eudialyte-group minerals are given in Table 1.

This paper summarizes structural data on EGMs in which Na prevails at the M2 site (below $\left.-{ }^{M 2} \mathrm{Na}-\mathrm{EGMs}\right)$. To date, the crystal structures of 23 samples of ${ }^{\mathrm{M} 2} \mathrm{Na}-\mathrm{EGMs}$ have been published. In this paper, we discuss the crystal chemical features of these minerals and provide some additional (chemical, IR spectroscopic and detailed crystal chemical) data on two samples of Fe-deficient EGMs whose crystal structures were reported elsewhere [24,31]. In addition, the significance of ${ }^{M 2} \mathrm{Na-EGMs}$ as markers of hyperagpaitic rocks is discussed. 
Table 1. Simplified crystal chemical formulae of eudialyte group minerals, including potentially new species (Samples 1 and 2). The key sites are indicated.

\begin{tabular}{|c|c|}
\hline Mineral & Simplified formula $(Z=3)$ \\
\hline Eudialyte & ${ }^{N 1-N 5} \mathrm{Na}_{15}{ }^{M 1} \mathrm{Ca}_{6}{ }^{M 2} \mathrm{Fe}^{2+}{ }_{3} \mathrm{Z}_{\mathrm{Zr}_{3}}{ }^{\mathrm{M} 3, M 4}\left[\mathrm{Si}_{2}\right]\left[\mathrm{Si}_{24} \mathrm{O}_{72}\right]\left(\mathrm{O}, \mathrm{OH}, \mathrm{H}_{2} \mathrm{O}\right)_{3}(\mathrm{Cl}, \mathrm{OH})_{2}$ \\
\hline $\begin{array}{l}\text { Mangano- } \\
\text { eudialyte }\end{array}$ & ${ }^{N 1-N 5} \mathrm{Na}_{14}{ }^{M 1} \mathrm{Ca}_{6}{ }^{M 2} \mathrm{Mn}_{3}{ }^{\mathrm{Z}} \mathrm{Zr}_{3}{ }^{M 3, M 4}\left[\mathrm{Si}_{2}\right]\left(\mathrm{Si}_{24} \mathrm{O}_{72}\right)\left[(\mathrm{OH})_{2} \mathrm{Cl}_{2}\right] \cdot 4 \mathrm{H}_{2} \mathrm{O}$ \\
\hline Fengchenite & N1-N5 $\left[\mathrm{Na}_{12} \square_{3}\right]^{M 1}(\mathrm{Ca}, \mathrm{Sr})_{6}{ }^{M 2} \mathrm{Fe}^{3+}{ }_{3} \mathrm{Z}_{\mathrm{Zr}_{3}}{ }^{M 3, M 4}\left[\mathrm{Si}_{2}\right]\left(\mathrm{Si}_{24} \mathrm{O}_{72}\right)\left(\mathrm{H}_{2} \mathrm{O}, \mathrm{OH}, \mathrm{O}\right)_{3}(\mathrm{OH}, \mathrm{Cl})_{2}$ \\
\hline Feklichevite & ${ }^{N 1-N 5}\left[\mathrm{Na}_{11} \mathrm{Ca}_{3}\right]{ }^{M 1} \mathrm{Ca}_{6}{ }^{M 2} \mathrm{Fe}^{3+}{ }_{2}{ }^{Z} \mathrm{Zr}_{3}{ }^{M 3, M 4}[\mathrm{SiNb}]\left(\mathrm{Si}_{24} \mathrm{O}_{72}\right)\left(\mathrm{OH}, \mathrm{H}_{2} \mathrm{O}, \mathrm{Cl}, \mathrm{O}\right)_{5}$ \\
\hline Golyshevite & ${ }^{N 1-N 5}\left[(\mathrm{Na}, \mathrm{Ca})_{10} \mathrm{Ca}_{3}\right]{ }^{M 1} \mathrm{Ca}_{6}{ }^{M 2} \mathrm{Fe}^{3+}{ }_{2} \mathrm{Z}_{\mathrm{Zr}_{3}}{ }^{M 3, M 4}[\mathrm{SiNb}]\left(\mathrm{Si}_{24} \mathrm{O}_{72}\right)\left(\mathrm{CO}_{3}\right)(\mathrm{OH})_{3} \cdot \mathrm{H}_{2} \mathrm{O}$ \\
\hline Taseqite & ${ }^{N 1-N 5}\left(\mathrm{Na}_{12} \mathrm{Sr}_{3}\right){ }^{M 1} \mathrm{Ca}_{6}{ }^{M 2} \mathrm{Fe}^{2+}{ }_{3} \mathrm{Z}_{\mathrm{Zr}_{3}}{ }^{M 3, M 4}[\mathrm{SiNb}]\left(\mathrm{Si}_{24} \mathrm{O}_{72}\right)\left(\mathrm{O}, \mathrm{OH}, \mathrm{H}_{2} \mathrm{O}\right)_{4} \mathrm{Cl}_{2}$ \\
\hline Mogovidite & $\left.{ }^{N 1-N 5}\left[\mathrm{Na}_{9}(\mathrm{Ca}, \mathrm{Na})_{6}\right]^{M 1} \mathrm{Ca}_{6}{ }^{M 2} \mathrm{Fe}^{3+}{ }_{2} \mathrm{Z}_{\mathrm{Zr}_{3}}{ }^{\mathrm{M} 3, M 4}[\square \mathrm{Si}]\left(\mathrm{Si}_{24} \mathrm{O}_{72}\right) \mathrm{CO}_{3}\right)\left(\mathrm{OH}, \mathrm{H}_{2} \mathrm{O}\right)$ \\
\hline Voronkovite & ${ }^{N 1-N 5} \mathrm{Na}_{15}{ }^{\mathrm{M} 1}\left[(\mathrm{Na}, \mathrm{Ca}, \mathrm{Ce})_{3}(\mathrm{Mn}, \mathrm{Ca})_{3}\right]^{M 2} \mathrm{Fe}^{2+}{ }_{3} \mathrm{Z}_{\mathrm{Zr}_{3}}{ }^{\mathrm{M} 3, M 4}\left[\mathrm{Si}_{2}\right]\left(\mathrm{Si}_{24} \mathrm{O}_{72}\right)(\mathrm{OH}, \mathrm{O})_{4} \mathrm{Cl} \cdot \mathrm{H}_{2} \mathrm{O}$ \\
\hline Georgbarsanovite & ${ }^{N 1-N 5}\left[\mathrm{Na}_{12} \mathrm{Mn}_{3}\right]{ }^{M 1} \mathrm{Ca}_{6}{ }^{M 2} \mathrm{Fe}^{2+}{ }_{3} \mathrm{Z}_{\mathrm{Zr}_{3}}{ }^{M 3, M 4}[\mathrm{SiNb}]\left(\mathrm{Si}_{24} \mathrm{O}_{72}\right)(\mathrm{O}, \mathrm{OH}, \mathrm{F})_{4} \mathrm{Cl} \cdot \mathrm{H}_{2} \mathrm{O}$ \\
\hline Kentbrooksite & ${ }^{N 1-N 5}(\mathrm{Na}, R E E)_{15}{ }^{M 1}(\mathrm{Ca}, R E E)_{6}{ }^{M 2} \mathrm{Mn}_{3} \mathrm{Z}_{\mathrm{Zr}_{3}}{ }^{\mathrm{M} 3, M 4}[\mathrm{SiNb}]\left(\mathrm{Si}_{24} \mathrm{O}_{74}\right) \mathrm{F}_{2} \cdot 2 \mathrm{H}_{2} \mathrm{O}$ \\
\hline $\begin{array}{l}\text { Ferrokent- } \\
\text { brooksite }\end{array}$ & ${ }^{N 1-N 5} \mathrm{Na}_{15}{ }^{M 1} \mathrm{Ca}_{6}{ }^{M 2} \mathrm{Fe}^{2+}{ }_{3} \mathrm{Z}_{\mathrm{Zr}_{3}}{ }^{M 3, M 4}[\mathrm{SiNb}]\left(\mathrm{Si}_{24} \mathrm{O}_{73}\right)\left(\mathrm{O}, \mathrm{OH}, \mathrm{H}_{2} \mathrm{O}\right)_{4}(\mathrm{Cl}, \mathrm{F}, \mathrm{OH})_{2}$ \\
\hline $\begin{array}{l}\text { Carbokent- } \\
\text { brooksite }\end{array}$ & ${ }^{N 1-N 5}(\mathrm{Na}, \square, R E E)_{15}{ }^{M 1} \mathrm{Ca}_{6}{ }^{M 2} \mathrm{Mn}_{3} \mathrm{Z}_{\mathrm{Zr}_{3}}{ }^{M 3, M 4}[\mathrm{SiNb}]\left(\mathrm{Si}_{24} \mathrm{O}_{74}\right) \mathrm{O}(\mathrm{OH})_{3}\left(\mathrm{CO}_{3}\right) \cdot \mathrm{H}_{2} \mathrm{O}$ \\
\hline Zirsilite-(Ce) & ${ }^{N 1-N 5}\left[(\mathrm{Na}, \square)_{12}(\mathrm{Ce}, \mathrm{Na})_{3}\right]^{M 1} \mathrm{Ca}_{6}{ }^{M 2} \mathrm{Mn}_{3} \mathrm{Z}_{\mathrm{Zr}_{3}}{ }^{M 3, M 4}[\mathrm{SiNb}]\left(\mathrm{Si}_{24} \mathrm{O}_{74}\right) \mathrm{O}(\mathrm{OH})_{3}\left(\mathrm{CO}_{3}\right) \cdot \mathrm{H}_{2} \mathrm{O}$ \\
\hline Ikranite & 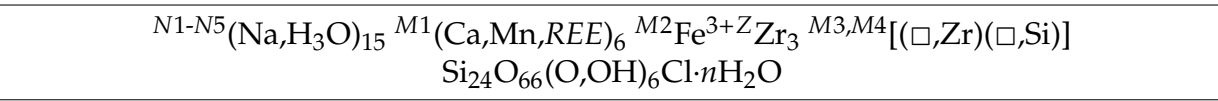 \\
\hline Andrianovite & ${ }^{N 1-N 5}\left[\mathrm{Na}_{12}(\mathrm{~K}, \mathrm{Sr}, \mathrm{Ce})_{3}\right]{ }^{M 1} \mathrm{Ca}_{6}{ }^{M 2} \mathrm{Mn}_{3}{ }^{\mathrm{Z}} \mathrm{Zr}_{3}{ }^{M 3, M 4}[\mathrm{SiNb}]\left(\mathrm{Si}_{24} \mathrm{O}_{73}\right)\left(\mathrm{O}, \mathrm{H}_{2} \mathrm{O}, \mathrm{OH}\right)_{5}$ \\
\hline Davinciite & ${ }^{N 1-N 5}\left[\mathrm{Na}_{12} \mathrm{~K}_{3}\right]{ }^{M 1} \mathrm{Ca}_{6}{ }^{M 2} \mathrm{Fe}^{2+}{ }_{3} \mathrm{Z}_{\mathrm{Zr}_{3}}{ }^{M 3, M 4}\left[\mathrm{Si}_{2}\right]\left[\left(\mathrm{Si}_{24} \mathrm{O}_{73} \mathrm{OH}\right)\right] \mathrm{Cl}_{2}$ \\
\hline Ilyukhinite & ${ }^{N 1-N 5}\left(\mathrm{H}_{3} \mathrm{O}, \mathrm{Na}\right)_{14}{ }^{M 1} \mathrm{Ca}_{6} \mathrm{Mn}^{2+}{ }_{2} \mathrm{Z}_{\mathrm{Zr}_{3}}{ }^{M 3, M 4}\left[\mathrm{Si}_{2}\right]\left[\mathrm{Si}_{24} \mathrm{O}_{72}(\mathrm{OH})_{2}\right] \cdot 3 \mathrm{H}_{2} \mathrm{O}$ \\
\hline Siudaite & $\begin{array}{c}{ }^{N 1-N 5}\left[\left(\mathrm{Na}, \mathrm{H}_{2} \mathrm{O}\right)_{12}\left(\mathrm{Mn}^{2+}{ }_{,} \mathrm{Na}\right)_{3}\right]{ }^{M 1} \mathrm{Ca}_{6}{ }^{M 2}\left(\mathrm{Fe}^{3+}{ }_{2} \mathrm{Mn}^{2+}\right){ }^{\mathrm{Z}} \mathrm{Zr}_{3}{ }^{M 3, M 4}[\mathrm{SiNb}]\left[\mathrm{Si}_{24} \mathrm{O}_{70}(\mathrm{OH})_{2}\right] \\
\left(\mathrm{OH}, \mathrm{O}, \mathrm{H}_{2} \mathrm{O}\right)_{5}\end{array}$ \\
\hline Raslakite & $\begin{aligned}{ }^{N 1-N 5} \mathrm{Na}_{15}{ }^{M 1}\left[\mathrm{Ca}_{3} \mathrm{Fe}_{3}\right]^{M 2}(\mathrm{Na}, \mathrm{Zr})_{3}{ }^{Z_{Z Z_{3}}{ }^{M 3, M 4}[(\mathrm{Si}, \mathrm{Nb}) \mathrm{Si}]\left(\mathrm{Si}_{24} \mathrm{O}_{72}\right)} \\
\left(\mathrm{OH}, \mathrm{H}_{2} \mathrm{O}, \mathrm{O}\right)_{4}(\mathrm{Cl}, \mathrm{OH})\end{aligned}$ \\
\hline Sergevanite & 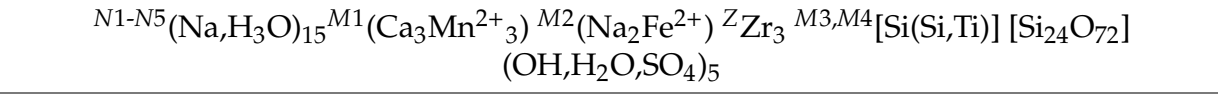 \\
\hline Aqualite & 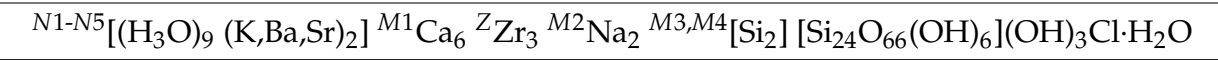 \\
\hline Oneillite & ${ }^{N 1-N 5} \mathrm{Na}_{15}{ }^{M 1}\left[\mathrm{Ca}_{3} \mathrm{Mn}_{3}\right]^{M 2} \mathrm{Fe}_{3} \mathrm{Z}_{\mathrm{Zr}_{3}}{ }^{\mathrm{M} 3, M 4}[\mathrm{SiNb}]\left(\mathrm{Si}_{24} \mathrm{O}_{72}\right)\left(\mathrm{O}, \mathrm{OH}, \mathrm{H}_{2} \mathrm{O}\right)_{4}(\mathrm{Cl}, \mathrm{OH})_{2}$ \\
\hline Khomyakovite & ${ }^{N 1-N 5}\left[\mathrm{Na}_{12} \mathrm{Sr}_{3}\right]^{M 1} \mathrm{Ca}_{6}{ }^{M 2} \mathrm{Fe}_{3}{ }^{Z} \mathrm{Zr}_{3}{ }^{M 3, M 4}[\mathrm{SiW}]\left(\mathrm{Si}_{24} \mathrm{O}_{72}\right)\left(\mathrm{O}, \mathrm{OH}, \mathrm{H}_{2} \mathrm{O}\right)_{4}(\mathrm{OH}, \mathrm{Cl})_{2}$ \\
\hline $\begin{array}{c}\text { Mangano- } \\
\text { khomyakovite }\end{array}$ & ${ }^{N 1-N 5}\left[\mathrm{Na}_{12} \mathrm{Sr}_{3}\right]{ }^{M 1} \mathrm{Ca}_{6}{ }^{M 2} \mathrm{Mn}_{3} \mathrm{Z}_{\mathrm{Zr}_{3}}{ }^{\mathrm{M} 3, M 4}[\mathrm{SiW}]\left(\mathrm{Si}_{24} \mathrm{O}_{72}\right)\left(\mathrm{O}, \mathrm{OH}, \mathrm{H}_{2} \mathrm{O}\right)_{4}(\mathrm{OH}, \mathrm{Cl})_{2}$ \\
\hline Johnsenite-(Ce) & 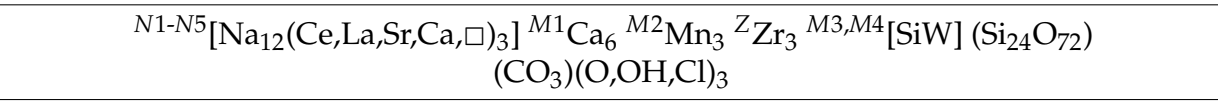 \\
\hline Alluaivite & 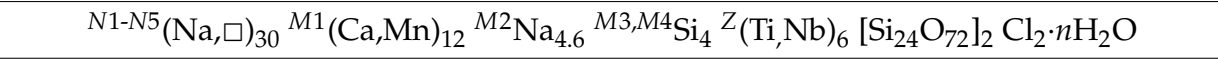 \\
\hline Dualite & $\begin{array}{c}{ }^{N 1-N 5} \mathrm{Na}_{30}{ }^{M 1}(\mathrm{Ca}, \mathrm{Na}, \mathrm{Ce}, \mathrm{Sr})_{12}{ }^{M 2}(\mathrm{Na}, \mathrm{Mn}, \mathrm{Fe}, \mathrm{Ti}){ }_{6}{ }^{\mathrm{Z}}\left[\mathrm{Zr}_{3} \mathrm{Ti}_{3}\right]^{M 3, M 4}\left[\mathrm{MnSi}_{3}\right] \\
{\left[\mathrm{Si}_{48} \mathrm{O}_{144}\right]\left(\mathrm{OH}, \mathrm{H}_{2} \mathrm{O}, \mathrm{Cl}\right]_{9}}\end{array}$ \\
\hline Labyrinthite & ${ }^{N 1-N 5} \mathrm{Na}_{32}{ }^{M 1} \mathrm{Ca}_{12}{ }^{M 2}\left[\mathrm{Na}_{3} \mathrm{Fe}_{2} \square\right]{ }^{\mathrm{Z}} \mathrm{Zr}_{6}{ }^{M 3, M 4}\left[\mathrm{Si}_{3} \mathrm{Ti}\right]\left[\mathrm{Si}_{3} \mathrm{O}_{9}\right]_{4}\left[\mathrm{Si}_{9} \mathrm{O}_{27}\right]_{4}(\mathrm{O}, \mathrm{OH})_{9} \mathrm{Cl}_{3}$ \\
\hline Rastsvetaevite & $\begin{array}{c}{ }^{N 1-N 5}\left[\mathrm{Na}_{26} \mathrm{~K}_{6}\right]^{M 1} \mathrm{Ca}_{12}{ }^{M 2}\left[\mathrm{NaK}_{2} \mathrm{Fe}_{3}\right]^{\mathrm{Z}} \mathrm{Zr}_{6}{ }^{M 3, M 4}\left[\mathrm{Si}_{4}\right]\left[\mathrm{Si}_{3} \mathrm{O}_{9}\right]_{4}\left[\mathrm{Si}_{9} \mathrm{O}_{27}\right]_{4} \\
\left(\mathrm{O}, \mathrm{OH}, \mathrm{H}_{2} \mathrm{O}\right)_{6} \mathrm{Cl}\end{array}$ \\
\hline Sample 1 & $\left.{ }^{N 1-N 5}\left(\mathrm{Na}, \mathrm{H}_{3} \mathrm{O}\right)_{13}{ }^{M 1}(\mathrm{Ca}, \mathrm{Mn})_{6}\right)^{Z} \mathrm{Zr}_{3}{ }^{M 2}\left[\mathrm{Na}_{2} \mathrm{Zr}\right]{ }^{M 3, M 4}\left[\mathrm{Si}_{2}\right]\left[\mathrm{Si}_{24} \mathrm{O}_{72}\right](\mathrm{OH})_{2} \mathrm{Cl} \cdot \mathrm{H}_{2} \mathrm{O}$ \\
\hline Sample 2 & ${ }^{N 1-N 5}\left(\mathrm{Na}, \mathrm{H}_{3} \mathrm{O}\right)_{15}{ }^{M 1} \mathrm{Ca}_{6}{ }^{Z} \mathrm{Zr}_{3}{ }^{M 2}\left[\mathrm{Na}_{2} \mathrm{Fe}\right]^{M 3, M 4}\left[\mathrm{Si}_{2}\right]\left[\mathrm{Si}_{24} \mathrm{O}_{72}\right](\mathrm{OH})_{2} \mathrm{Cl} \cdot 2 \mathrm{H}_{2} \mathrm{O}$ \\
\hline
\end{tabular}




\section{Materials and Methods}

Sample 1 (sample Kdk-6626) was collected from the Kedykverpakhk area of the Karnasurt underground loparite mine at Mt. Kedykverpakhk in the northwest part of the Lovozero alkaline massif. The studied EGM occurs as transparent, reddish, equant grains up to $1.5 \mathrm{~mm}$ across in a peralkaline (hyperagpaitic) foyaite near the contact point with the loparite malignite layer. This rock mainly consists of potassic feldspar, nepheline, sodalite and aegirine, and contains accessory EGM, lamprophyllite, lomonosovite, loparite and interstitial villiaumite.

Sample 2 originates from the Kvanefjeld area, Ilímaussaq alkaline complex. It comprises brownish yellow grains and imperfect equant crystals up to $2 \mathrm{~mm}$ across in an agpaitic rock composed of potassic feldspar, albite, nepheline, aegirine and arfvedsonite.

Electron microprobe analyses (three spot analyses for each sample) were carried out using a Tescan VEGA-II XMU electronic microscope (EDS mode, 20 kV, 400 pA, Oxford Instruments plc, London, UK) housed at the Institute of Experimental Mineralogy RAS. Data reduction was carried out by means of a modified INCA Energy 450 software package (Oxford Instruments, Oxfordshire, UK). The size of the electron beam was $157-180 \mathrm{~nm}$. The beam was rastered on an area $20 \mu \mathrm{m} \times 20 \mu \mathrm{m}$ in order to minimize sample damage. The time of data acquisition was $50 \mathrm{~s}$. The sample-to-detector distance was $25 \mathrm{~mm}$. The standards used were: albite for $\mathrm{Na}$ and $\mathrm{Si}$, sanidine for $\mathrm{K}$, wollastonite for $\mathrm{Ca}, \mathrm{BaSO}_{4}$ for $\mathrm{S}, \mathrm{SrF}_{2}$ for $\mathrm{Sr}$, individual $\operatorname{REE}\left(\mathrm{PO}_{4}\right)$ for rare-earth elements, metallic $\mathrm{Fe}, \mathrm{Mn}, \mathrm{Ti}, \mathrm{Zr}, \mathrm{Hf}$ and $\mathrm{Nb}$ for corresponding elements, and $\mathrm{NaCl}$ for $\mathrm{Cl}$. The contents of other elements with atomic numbers $>8$ were below detection limits. $\mathrm{H}_{2} \mathrm{O}$ was not determined directly because of the paucity of material.

In order to obtain infrared (IR) absorption spectra, powdered samples were mixed with dried $\mathrm{KBr}$, pelletized and analyzed using an ALPHA FTIR spectrometer (Bruker Optics, Karlsruhe, Germany) in the range $360-4000 \mathrm{~cm}^{-1}$ with a resolution of $4 \mathrm{~cm}^{-1}$ and 16 scans. An IR spectrum of an analogous pellet prepared from pure $\mathrm{KBr}$ was used as a reference.

\section{Results}

\subsection{Chemical Composition of Samples 1 and 2}

The chemical data of Samples 1 and 2 are presented in Table 2. The empirical formulae calculated on 25.48 and $25.80 \mathrm{Si}$ atoms per formula unit, respectively (in accordance with structural data, $Z=3$, see below) are as follows.

Sample 1:

$\left(\mathrm{H}_{2} \mathrm{O}, \mathrm{H}_{3} \mathrm{O}\right)_{x} \mathrm{Na}_{13.65} \mathrm{~K}_{0.18} \mathrm{Ca}_{3.90} \mathrm{Mn}_{1.22} \mathrm{Fe}_{0.90} \mathrm{Sr}_{0.33} \mathrm{La}_{0.17} \mathrm{Ce}_{0.20} \mathrm{Nd}_{0.06} \mathrm{Ti}_{0.33} \mathrm{Zr}_{3.79} \mathrm{Hf}_{0.03} \mathrm{Nb}_{0.22} \mathrm{Si}_{25.48}$ $\mathrm{S}_{0.15} \mathrm{Cl}_{0.80}(\mathrm{O}, \mathrm{OH})_{y}$.

Sample 2:

$\left(\mathrm{H}_{2} \mathrm{O}, \mathrm{H}_{3} \mathrm{O}\right)_{x} \mathrm{Na}_{10.39} \mathrm{Ca}_{4.19} \mathrm{Mn}_{0.34} \mathrm{Fe}_{1.36} \mathrm{Y}_{0.28} \mathrm{La}_{0.33} \mathrm{Ce}_{0.37} \mathrm{Nd}_{0.09} \mathrm{Ti}_{0.33} \mathrm{Zr}_{2.61} \mathrm{Hf}_{0.03} \mathrm{Nb}_{0.23} \mathrm{Si}_{25.80} \mathrm{~S}_{0.08}$ $\mathrm{Cl}_{0.35}(\mathrm{O}, \mathrm{OH})_{y}$.

Table 2. Chemical composition of the studied Fe-deficient EGMs (in wt.\%).

\begin{tabular}{ccccc}
\hline \multirow{2}{*}{ Constituent } & \multicolumn{2}{c}{ Sample 1 } & \multicolumn{2}{c}{ Sample 2 } \\
\cline { 2 - 5 } & Mean & Ranges & Mean & Ranges \\
\hline $\mathrm{Na}_{2} \mathrm{O}$ & 13.81 & $13.42-14.17$ & 11.13 & $10.38-11.71$ \\
\hline $\mathrm{K}_{2} \mathrm{O}$ & 0.27 & $b d l-0.53$ & $b d l$ & $b d l$ \\
\hline $\mathrm{CaO}$ & 7.13 & $6.80-7.56$ & 8.13 & $7.77-8.60$ \\
\hline $\mathrm{MnO}$ & 2.83 & $2.43-3.15$ & 0.83 & $0.59-0.96$ \\
\hline $\mathrm{FeO}$ & 2.10 & $1.27-2.71$ & 3.38 & $3.04-3.75$ \\
\hline $\mathrm{SrO}$ & 1.12 & $1.67-2.31$ & $b d l$ & $b d l$ \\
\hline $\mathrm{Y}_{2} \mathrm{O}_{3}$ & $b d l$ & $b d l$ & 1.08 & $0.72-1.27$ \\
\hline
\end{tabular}


Table 2. Cont.

\begin{tabular}{ccccc}
\hline \multirow{2}{*}{ Constituent } & \multicolumn{2}{c}{ Sample 1 } & \multicolumn{2}{c}{ Sample 2 } \\
\cline { 2 - 5 } & Mean & Ranges & Mean & Ranges \\
\hline $\mathrm{La}_{2} \mathrm{O}_{3}$ & 0.91 & $0.68-1.15$ & 1.85 & $1.63-2.05$ \\
\hline $\mathrm{Ce}_{2} \mathrm{O}_{3}$ & 1.06 & $0.86-1.39$ & 2.12 & $1.88-2.40$ \\
\hline $\mathrm{Nd}_{2} \mathrm{O}_{3}$ & 0.34 & $0.21-0.48$ & 0.50 & $0.41-0.66$ \\
\hline $\mathrm{SiO}_{2}$ & 49.97 & $49.05-50.89$ & 53.60 & $52.59-54.82$ \\
\hline $\mathrm{TiO}_{2}$ & 0.87 & $0.69-1.04$ & 0.92 & $0.76-1.18$ \\
\hline $\mathrm{ZrO}_{2}$ & 15.24 & $14.88-15.57$ & 11.13 & $10.84-11.43$ \\
\hline $\mathrm{HfO}_{2}$ & 0.18 & $b d l-0.30$ & 0.23 & $b d l-0.39$ \\
\hline $\mathrm{Nb}_{2} \mathrm{O}_{5}$ & 0.91 & $0.79-1.11$ & 1.05 & $0.85-1.26$ \\
\hline $\mathrm{SO}_{3}$ & 0.38 & $b d l-0.63$ & 0.23 & $b d l-0.37$ \\
\hline $\mathrm{Cl}$ & 0.93 & $0.70-1.27$ & 0.43 & $0.36-0.48$ \\
\hline$-\mathrm{O}=\mathrm{Cl}$ & -0.21 & & -0.10 & \\
\hline $\mathrm{Total}$ & 97.84 & & 96.51 & \\
\hline $\mathrm{N}$ & & &
\end{tabular}

Note: $b d l=$ below detection limit; EGM = eudialyte-group minerals.

\subsection{Infrared Spectroscopy of Samples 1 and 2}

The IR spectra of Samples 1 and 2 (Figure 2) contain bands of O-H stretching vibrations (in the range $3200-3700 \mathrm{~cm}^{-1}$ ), H-O-H bending vibrations (at 1650 and $1635 \mathrm{~cm}^{-1}$ ), stretching vibrations of the rings of tetrahedra (in the range 1000-1100 $\mathrm{cm}^{-1}$ ) and $\mathrm{SiO}_{4}$ tetrahedra at the $M 3$ and $M 4$ sites (at the centers of 9-membered rings of tetrahedra) at 933 and $936 \mathrm{~cm}^{-1}$. Broad absorption in the range $2600-3300 \mathrm{~cm}^{-1}$ indicates the presence of $\mathrm{H}_{3} \mathrm{O}^{+}$groups. Bands in the range $650-750 \mathrm{~cm}^{-1}$ correspond to mixed vibrations of the rings of tetrahedra ("ring bands"). Weak absorptions in the region $510-530 \mathrm{~cm}^{-1}$ are related to $\mathrm{Zr}-\mathrm{O}$ and $\mathrm{Fe}-\mathrm{O}$ stretching modes of the M2-centered polyhedra. Bands below $500 \mathrm{~cm}^{-1}$ are due to lattice mode involving predominantly bending vibrations of rings of tetrahedra, and stretching vibrations of $\mathrm{M} 1$-centered octahedra. Bands of $\mathrm{CO}_{3}{ }^{2-}$ are absent in both spectra. The assignment of IR bands was made based on analyses of the IR spectra of several dozen structurally investigated eudialyte-group minerals, in accordance with [2].

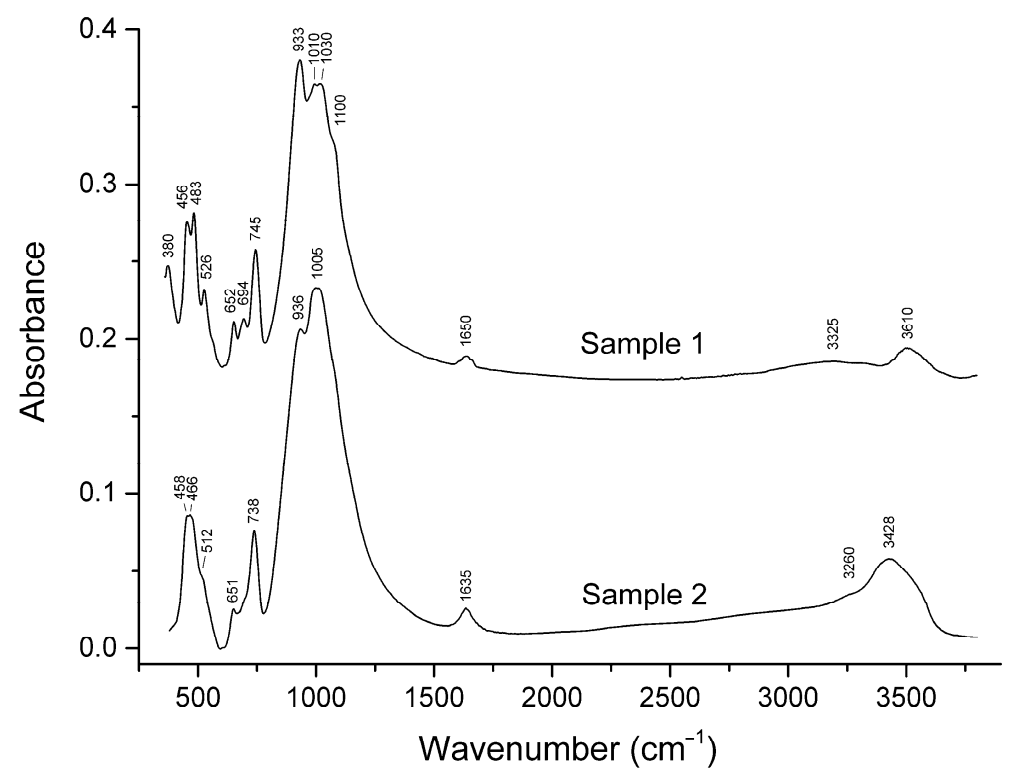

Figure 2. Infrared absorption spectra of Samples 1 and 2. The curves are offset for comparison. 
The number of observed absorption maxima and shoulders in the IR spectrum of Sample 2 is less than in the IR spectrum of Sample 1. This is due to a high content of $\mathrm{H}_{2} \mathrm{O}$ molecules and $\mathrm{H}_{3} \mathrm{O}^{+}$ groups in Sample 2. The disordering of $\mathrm{Na}^{+}, \mathrm{H}_{2} \mathrm{O}$ and $\mathrm{H}_{3} \mathrm{O}^{+}$, as well as hydrogen bonding, result in the broadening of individual bands, their poor resolution and changes of peak intensities which are most significant for narrow bands.

\subsection{Crystal Chemistry of Samples 1 and 2}

The crystal structures of Samples 1 and 2 are published elsewhere [24,31]. In this subsection, we discuss only the crystal-chemical features in the microregions around the key sites $M 2-M 4$ (see Table 3).

Table 3. Selected interatomic $M-\mathrm{O}$ distances $(\AA)$ in the structures of the Samples 1 and 2.

\begin{tabular}{cccccccc}
\hline \multicolumn{3}{c}{ Sample 1 } & \multicolumn{3}{c}{ Sample 2 } \\
\hline Site & $\begin{array}{c}\text { Coord. } \\
\text { Number }\end{array}$ & Ranges & Average & Site & $\begin{array}{c}\text { Coord. } \\
\text { Number }\end{array}$ & Ranges & Average \\
\hline$M 1$ & 6 & $2.295(8)-2.420(5)$ & 2.350 & $M 1$ & 6 & $2.305(6)-2.394(3)$ & 2.338 \\
\hline M2a & 7 & $2.328(9)-3.045(8)$ & 2.754 & $M 2 \mathrm{a}$ & 5 & $2.14(4)-2.34(1)$ & 2.24 \\
\hline M2b & 5 & $2.138(5)-2.31(7)$ & 2.204 & $M 2 \mathrm{~b}$ & 4 & $2.184(3)-2.184(3)$ & 2.184 \\
\hline M3a & 6 & $1.614(9)-1.94(2)$ & 1.777 & $M 3 \mathrm{a}$ & 6 & $1.66(1)-1.99(4)$ & 1.83 \\
\hline$M 3 \mathrm{~b}$ & 4 & $1.28(3)-1.53(1)$ & 1.47 & $M 3 c$ & 4 & $1.565(9)-1.67(3)$ & 1.59 \\
\hline$M 3 \mathrm{c}$ & 4 & $1.602(7)-1.63(1)$ & 1.609 & & & & \\
\hline M4a & 4 & $1.535(2)-1.62(3)$ & 1.556 & & & & \\
\hline$M 4 \mathrm{~b}$ & 4 & $1.611(4)-1.82(4)$ & 1.66 & & & & \\
\hline$M 4 \mathrm{c}$ & 6 & $1.79(8)-1.903(7)$ & 1.847 & & & & \\
\hline
\end{tabular}

Sample 1 is trigonal, space group $R 3 m$; the unit cell parameters are $a=14.198(1) \AA, c=30.380(1) \AA$, and $V=5303.9(1) \AA^{3}$. The crystal structure was refined to a final reliability factor value $R=4.2 \%$ in the anisotropic approximation of atomic displacements using 3174 reflections with $F>3 \sigma(F)[22]$. All features of the distribution of cations between different sites in the structure of Sample 1 are reflected in its crystal chemical formula $(Z=3)$ :

$\left.\mathrm{Z}_{\mathrm{Zr}_{3}{ }^{M 1}\left[\mathrm{Ca}_{3.9} \mathrm{Mn}_{1.2} \mathrm{Fe}_{0.9}\right]}{ }^{N 1-5}\left[\mathrm{Na}_{11.4}\left(\mathrm{H}_{3} \mathrm{O}, \mathrm{H}_{2} \mathrm{O}\right){ }_{1.8} \mathrm{Ce}_{0.45} \mathrm{Sr}_{0.4} \mathrm{~K}_{0.2}\right]^{M 2}\left[\mathrm{Na}^{\mathrm{VII}}{ }_{2.13} \mathrm{Zr}^{\mathrm{V}}{ }_{0.87}\right)\right]\left[\mathrm{Si}_{24} \mathrm{O}_{72}\right]$ ${ }^{M 3}-4\left[\mathrm{Si}_{1.48} \mathrm{Ti}_{0.31} \mathrm{Nb}_{0.21}\right]^{X}\left[(\mathrm{OH})_{2.9}\left(\mathrm{H}_{2} \mathrm{O}\right)_{1.26}(\mathrm{Cl}, \mathrm{S})_{0.94}\right]$, where the compositions of key sites are given in square brackets, and roman numerals denote coordination numbers. The simplified formula is $\left(\mathrm{Na}, \mathrm{H}_{3} \mathrm{O}\right)_{13}\left(\mathrm{Ca}_{4} \mathrm{Mn}_{2}\right) \mathrm{Zr}_{3}\left(\mathrm{Na}_{2} \mathrm{Zr}\right)\left[\mathrm{Si}_{26} \mathrm{O}_{72}\right](\mathrm{OH})_{2} \mathrm{Cl} \cdot \mathrm{H}_{2} \mathrm{O}$.

An excess of $\mathrm{Zr}$ (0.87 atoms per formula unit) was located at the $M 2 \mathrm{a}$ site in the square base pyramid with apical OH group and average $\mathrm{Zr}-\mathrm{O}$ distance of $2.204 \AA$. This vertex also belongs to the $\mathrm{NbO}_{6}$ octahedron located on the threefold axis, which results in the formation of a cluster $\left[\mathrm{NbZr}_{3} \mathrm{O}_{3}\right]$ whose occupancy factor is equal to 0.21 .

A large, elongated, Na-centered, seven-fold $M 2 \mathrm{~b}$ polyhedron is characterized by the average $\mathrm{Na}-\mathrm{O}$ distance of $2.754 \AA$. One base of this prism-like polyhedron is square, and another is a triangle involving two $\mathrm{O}$ atoms in the framework and one $\mathrm{Cl}$ atom located on the threefold axis. These two M2 polyhedra are turned in opposite directions and are only partially occupied, since the distance between the cations centering them is short, amounting to $1.781 \AA$.

The key sites M3 and M4 on the threefold axis are statistically occupied by Si-centered tetrahedra of two orientations with a common triangular base, and subordinate $\mathrm{Ti}$ and $\mathrm{Nb}$ atoms in octahedral coordination.

Large extra-framework cations are located at the sites N1-N4, which are split and mainly occupied by sodium atoms coordinated by 7 - and 8-fold polyhedra with average distances within the range 
of 2.56-2.64 A. Based on the number of refined electrons, one may suppose that the group of closely spaced N5 sites is occupied by hydronium groups and water molecules.

Short distances $(\AA)$ between statistically occupied cationic sites in Sample 1 are: $M 2 a-M 2 b=1.781(7)$; $M 3 \mathrm{a}-M 3 \mathrm{~b}=0.23(3) ; M 3 \mathrm{a}-M 3 \mathrm{c}=1.37(1) ; M 3 \mathrm{~b}-M 3 \mathrm{c}=1.14(2) ; M 4 \mathrm{a}-M 4 \mathrm{~b}=0.87(1) ; M 4 \mathrm{~b}-M 4 \mathrm{c}=0.59(1) ;$ $M 4 \mathrm{a}-M 4 \mathrm{c}=1.46(1) ; N 1 \mathrm{a}-N 1 \mathrm{~b}=0.72(1) ; N 2 \mathrm{a}-N 2 \mathrm{~b}=0.50(1) ; N 4 \mathrm{a}-N 4 \mathrm{~b}=0.27(4) ; N 4 \mathrm{a}-N 4 c=0.71(1) ;$ $N 4 \mathrm{~b}-N 4 \mathrm{c}=0.95(3)$.

Sample 2 is trigonal, space group $R-3 m$; the unit cell parameters are $a=14.208(1) \AA$, $c=30.438(2) \AA$, and $V=5321(1) \AA^{3}$. The crystal structure is refined to the final $R=5.6 \%$ for 1095 reflections with $F>3 \sigma(F)$ in the anisotropic approximation of atomic displacements [31]. The crystal chemical formula $(\mathrm{Z}=3)$ is ${ }^{\mathrm{Z}}\left[\mathrm{Zr}_{2.57} \mathrm{Ti}_{0.4} \mathrm{Hf}_{0.03}\right]{ }^{M 1}\left[\mathrm{Ca}_{4.3} \mathrm{Fe}_{0.5} \mathrm{Mn}_{0.4} \mathrm{Na}_{0.3} \mathrm{Y}_{0.3} \mathrm{Ce}_{0.2}\right]{ }^{M 2}\left[{ }^{\mathrm{V}} \mathrm{Na}_{2}{ }^{\mathrm{IV}} \mathrm{Fe}\right]$ ${ }^{M 3}\left[\mathrm{Si}_{1.8} \mathrm{Nb}_{0.2}(\mathrm{OH})_{2.4}\right]^{N 1-5}\left[\mathrm{Na}_{6}\left(\mathrm{Na}_{3} \mathrm{H}_{3} \mathrm{O}, \mathrm{H}_{2} \mathrm{O}\right)_{8.4} \mathrm{Ce}_{0.6}\right]\left[\mathrm{Si}_{24} \mathrm{O}_{72}\right]{ }^{X}\left[\left(\mathrm{H}_{2} \mathrm{O}\right)_{2.0} \mathrm{Cl}_{0.4}\right]$. The simplified formula is $\left(\mathrm{Na}, \mathrm{H}_{3} \mathrm{O}\right)_{15} \mathrm{Ca}_{6} \mathrm{Zr}_{3}\left[\mathrm{Na}_{2} \mathrm{Fe}\right]\left[\mathrm{Si}_{26} \mathrm{O}_{72}\right](\mathrm{OH})_{2} \mathrm{Cl} \cdot 2 \mathrm{H}_{2} \mathrm{O}$.

The centrum of the $\mathrm{M} 2$ square is populated by Fe with an occupancy factor of 0.33 and $\mathrm{Fe}-\mathrm{O}$ distances of $2.184 \AA$. Na atoms occupy two sites on both sides of the $M 2$ square and are coordinated by additional $\mathrm{OH}$ groups with an average $\mathrm{Na}-\mathrm{O}$ distance in the square pyramids of $2.236 \AA$. Since both Na subsites are located at short distances from the center of the square $(0.59 \AA)$ and from each other $(1.18 \AA)$, only one of them can be occupied in this microregion. The total occupancy factor of the three $M 2$ subsites is equal to 1 , which corresponds to two $\mathrm{Na}$ atoms and one Fe atom per formula unit $(\mathrm{Z}=3)$.

The M3 microregion situated at the threefold axis contains two sites, one of which (with an occupancy factor of 0.8 and an average $\mathrm{Si}-\mathrm{O}$ distance of $1.59 \AA$ ) contains $\mathrm{Si}$ in tetrahedral coordination, and another which contains $\mathrm{Si}$ with minor admixture of octahedrally coordinated $\mathrm{Nb}$ with an average $\mathrm{Nb}-\mathrm{O}$ distance in the $\mathrm{NbO}_{6}$ octahedron of $1.83 \AA$.

The N1b and N2a sites, located at the short distance of 0.48(1) $\AA$ from each other, are occupied by $\mathrm{H}_{3} \mathrm{O}^{+}$and $\mathrm{H}_{3} \mathrm{O}^{+}$with an admixture of $L n$, respectively. Both sites have 8-fold coordination with the cation-oxygen distances in the ranges $2.56-2.69$ and 2.48-3.04 $\AA$, respectively.

The N4-site is split into two subsites ( $N 4 \mathrm{a}$ and $N 4 \mathrm{~b}$ ) having 10 -fold coordination and partially occupied by $\mathrm{Na}$ (with the occupancy factors of 0.6 and 0.4 , respectively). The distances $\mathrm{N} 4 \mathrm{a}-\mathrm{O}, \mathrm{N} 4 \mathrm{~b}-\mathrm{O}$ and N4a-N4b are 2.46-2.99, 2.38-3.08 and $0.52 \AA$, respectively. Based on the number of refined electrons, and by analogy with other hydrated EGMs, one can suppose that The $\mathrm{N} 5$ hole is occupied by $\mathrm{H}_{3} \mathrm{O}^{+}$ cations, $\mathrm{H}_{2} \mathrm{O}$ molecules and $\mathrm{OH}$ groups belonging to the $\mathrm{SiO}_{3}(\mathrm{OH})$ tetrahedron attached to the center of the $\mathrm{Si}_{9} \mathrm{O}_{27}$ ring.

Other short distances (in $\AA$ ) between statistically occupied cationic sites in Sample 2 are $M 2 a-M 2 b=0.590(1), M 3 b-M 3 c=1.19(2), N 1 a-N 1 b=0.48(1), N 3 a-N 3 b=0.52(1)$ and N5-N5 = 2.00(4).

\section{Discussion}

About 150 years have passed since the description of eudialyte by Stromeyer in 1819 [1], but the structure of this mineral remained unknown for a long time, since it has a volume of more than $5000 \AA^{3}$. Another cause of this situation was unique crystal-chemical complexity and variability of eudialyte and related minerals (Tables 1 and 4).

Table 4. EGMs containing $\mathrm{Na}$ at the $\mathrm{M} 2$ site.

\begin{tabular}{cccc}
\hline Sample No. & $\begin{array}{c}\text { Lattice Parameters } \\
(a, c \text { in } \AA) ; \\
\text { Space Group }\end{array}$ & $\begin{array}{c}\text { Na-Polyhedra } \\
(\mathbf{Z}=3)\end{array}$ & References \\
\hline \multicolumn{4}{c}{ Eudialyte Structure Type } \\
\hline 1. & $14.198(1), 30.380(1) ; R 3 m$ & $\mathrm{Na}_{2.1}$ & {$[24]$} \\
\hline 2. & $14.208(1), 30.438(2) ; R-3 m$ & $\mathrm{Na}_{2.01}$ & {$[31]$} \\
\hline 3. & $14.226(4), 30.339(7) ; R-3 m$ & $\mathrm{Na}^{\mathrm{VII}}{ }_{2.2}$ & {$[32]$} \\
\hline 4. & $14.199(1), 30.305(1) ; R 3 m$ & $\mathrm{Na} \mathrm{VI}_{0.7}+\mathrm{Na}_{0.6}$ & {$[29]$} \\
\hline
\end{tabular}


Table 4. Cont.

\begin{tabular}{|c|c|c|c|}
\hline Sample No. & $\begin{array}{c}\text { Lattice Parameters } \\
\text { (a, } c \text { in } \AA \text { ); } \\
\text { Space Group }\end{array}$ & $\begin{array}{l}\text { Na-Polyhedra } \\
\qquad(Z=3)\end{array}$ & References \\
\hline 5. & 14.155(1), 30.998(1); R3m & $\mathrm{Na}^{\mathrm{IV}} 2.3$ & [33] \\
\hline 6. & $14.081(1), 30.525(3) ; R 3 m$ & $\mathrm{Na}^{\mathrm{IV}}{ }_{0.62}$ & [33] \\
\hline 7. & $14.170(4), 30.38(2) ; R 3 m$ & $\mathrm{Na}^{\mathrm{IV}}{ }_{2.4}$ & {$[34]$} \\
\hline 8. & $14.165(1), 30.600(5) ; R 3 m$ & $\mathrm{Na}^{\mathrm{VI}} 2.2$ & [35] \\
\hline 9. & $14.220(1), 30.539(1) ; R 3 m$ & $\mathrm{Na}_{1.9}$ & {$[2]$} \\
\hline \multicolumn{4}{|c|}{ Raslakite Structure Type } \\
\hline 10. & $14.208(1), 30.384(1) ; R 3$ & $\mathrm{Na}^{\mathrm{IV}} 2.4$ & [30] \\
\hline 11. & $14.1944(4), 30.294(1) ; R 3$ & $\mathrm{Na}^{\mathrm{VII}} 1.75$ & [27] \\
\hline 12. & $14.229(7), 30.019(5) ; R 3$ & $\mathrm{Na}_{1.5}$ & {$[36,37]$} \\
\hline 13. & $14.218(1), 30.349(2) ; R 3$ & $\mathrm{Na}^{\mathrm{IV}}{ }_{1.8}+\mathrm{Na}^{\mathrm{VI}}{ }_{0.6}$ & {$[30,38]$} \\
\hline 14. & $14.078(3), 31.24(1) ; R 3$ & $\mathrm{Na}^{\mathrm{IV}} 2.2$ & {$[39,40]$} \\
\hline 15. & 14.182(7), 30.37(1); R3 & $\mathrm{Na}_{1.8}$ & {$[41]$} \\
\hline 16. & $14.222(3), 30.165(5) ; R 3$ & $\mathrm{Na}_{0.9}+\mathrm{Na}_{0.45}$ & {$[42,43]$} \\
\hline \multicolumn{4}{|c|}{ Alluaivite Structure Type } \\
\hline 17. & $14.046(2), 60.60(2) ; R-3 m$ & $\mathrm{Na}^{\mathrm{IV}}{ }_{3} / \mathrm{Na}^{\mathrm{VII}}{ }_{2.34}$ & {$[44]$} \\
\hline 18. & $14.069(4), 60.63(1) ; R-3 m$ & $\mathrm{Na}^{\mathrm{IV}}{ }_{3} / \mathrm{Na}^{\mathrm{IV}}{ }_{1.59}$ & {$[21]$} \\
\hline 19. & 14.153(9), 60.72(5); $R 3 m$ & $\mathrm{Na}_{1.5} / \mathrm{Na} \mathrm{V}_{1.5}$ & {$[45,46]$} \\
\hline 20. & $14.239(1), 60.733(7) ; R 3$ & $\mathrm{Na}^{\mathrm{IV}}{ }_{1} \mathrm{Na}^{\mathrm{VII}}{ }_{2} / \mathrm{Fe}^{\mathrm{IV}}{ }_{2.2}$ & {$[47,48]$} \\
\hline 21. & $14.249(1), 60.969(1) ; R 3 m$ & $\mathrm{Na}^{\mathrm{IV}}{ }_{1} \mathrm{~K}^{\mathrm{VII}}{ }_{2} / \mathrm{Fe}^{\mathrm{IV}}{ }_{3}$ & {$[49,50]$} \\
\hline 22. & $14.179(1), 60.67(1) ; R-3 m$ & $\mathrm{Na}^{\mathrm{IV}}{ }_{2.4} / \mathrm{Mn} \mathrm{V}_{2.46}$ & {$[51]$} \\
\hline 23. & $\begin{array}{c}14.2032(1), 60.6118(7) ; \\
R-3 m\end{array}$ & $\mathrm{Na}^{\mathrm{IV}}{ }_{3} / \mathrm{Fe}^{\mathrm{IV}} 1.25$ & [10] \\
\hline
\end{tabular}

Note: Roman numerals denote coordination numbers. A part of the data corresponds to holotype samples of EGMs: raslakite (12), sergevanite (13), aqualite (14), alluaivite (17), dualite (19), labirinthite (20) and rastsvetaevite (21).

Only in the early 1970s was the structural motive of eudialyte characterized in general terms by a group of researchers led by academician N.V. Belov [52,53], and almost simultaneously by G. Giuseppetti et al. [54]. Further studies of the structure of eudialyte revealed its complexity and variety of structural fragments.

Mineral species belonging to the eudialyte group are distinguished by symmetry (representatives with the space groups $R 3 m, R-3 m$ and $R 3$ are known) and different combinations of predominant components at the key sites [2-7]. In addition, there is a subgroup of EGMs with modular structures and doubled $c$ parameter of the unit cell. The distribution of cations among key sites is the result of a combination of two factors: the competition of their activities in the mineral-forming medium, and their affinity to different sites in the structures of EGMs.

The structural complexity of EGMs results from an unusual diversity of their fragments, including a three-membered ring of tetrahedra $\left(\mathrm{Si}_{3} \mathrm{O}_{9}\right)$, two nonequivalent, nine-membered rings of tetrahedra $\left(\mathrm{Si}_{9} \mathrm{O}_{27}\right)$ and a six-membered ring of edge-sharing octahedra $\mathrm{M1}_{6} \mathrm{O}_{24}\left(\mathrm{M1}=\mathrm{Ca}, \mathrm{Mn}^{2+}, \mathrm{Fe}^{2+}, \mathrm{Na}, \mathrm{Ln}\right.$, Sr: Figure 3) combined into a heteropolyhedral framework via isolated $\mathrm{ZO}_{6}$ octahedra. Additional key sites $M 3$ and $M 4$ are located at the centers of the $\mathrm{Si}_{9} \mathrm{O}_{27}$ rings, and can be vacant or occupied by different components, including ${ }^{[4]} \mathrm{Si},{ }^{[4]} \mathrm{Al},{ }^{[6]} \mathrm{Nb},{ }^{[6]} \mathrm{W}$, $\mathrm{Na}$. Large cations $\left(\mathrm{Na}^{+}, \mathrm{K}^{+}, \mathrm{H}_{3} \mathrm{O}^{+}, \mathrm{Ca}^{2+}, \mathrm{Sr}^{2+}\right.$, $R E E^{3+}$, etc.) occupy extra-framework sites $\mathrm{N1}-\mathrm{N} 5$, which are typically split. Additional anions $\left(\mathrm{Cl}^{-}, \mathrm{F}^{-}\right.$, $\mathrm{OH}^{-}, \mathrm{S}^{2-}, \mathrm{SO}_{4}{ }^{2-}, \mathrm{CO}_{3}{ }^{2-}$ ) and water molecules occur at two sites on the threefold axis. 


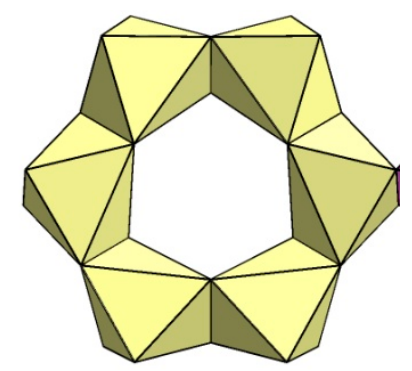

Figure 3. Six-membered ring composed of $M 1$ octahedra in the eudialyte-type structure.

The crystallochemical diversity of EGMs is determined by complex mechanisms of isomorphism accompanied by the splitting of positions and variations in their coordination numbers [2]. The most complex isomorphism schemes are realized at the group of the $M 2$ sites in the microregion between two neighboring $M 1_{6} \mathrm{O}_{24}$ octahedra. Eudialyte s.s. is a Na- and Si-rich EGM in which the M2 site is occupied by $\mathrm{Fe}^{2+}$ with flat-square coordination. However, different Fe-deficient members of the eudialyte group are known. In these minerals, the deficiency of iron at the $M 2$ site is compensated for by other cations $\left(\mathrm{Fe}^{2+}, \mathrm{Fe}^{3+}, \mathrm{Ti}^{4+}, \mathrm{Hf}^{4+}, \mathrm{Zr}^{4+}, \mathrm{Ta}^{5+}, \mathrm{Mn}^{2+}\right.$, and $\left.\mathrm{Mg}^{2+}\right)$. The agpaitic and, especially, hyperagpaitic rocks of some alkaline massifs are characterized by the prevalence of ${ }^{M 2} \mathrm{Na}$-dominant minerals over other EGMs.

The substitution of $\mathrm{Fe}^{2+}$ by $\mathrm{Na}^{+}$(usually accompanied by the change of the coordination number from 4 to 5,6 or 7) is a specific crystal-chemical feature of these EGMs. Additional $\mathrm{O}$ atoms coordinating ${ }^{M 2} \mathrm{Na}$ belong to $\mathrm{H}_{2} \mathrm{O}$ molecules or to $\mathrm{OH}$ groups of the $M 3(\mathrm{O}, \mathrm{OH})_{6}$ and $M 4(\mathrm{O}, \mathrm{OH})_{6}$ octahedra or $\mathrm{SiO}_{3}(\mathrm{OH})$ tetrahedra occurring on the threefold axes at the centers of the $\mathrm{Si}_{9} \mathrm{O}_{27}$ rings. The 5-, 6- and 7-fold Na-centered $M 2$ polyhedra are based on the square formed by four $\mathrm{O}$ atoms of the neighboring $\mathrm{M1}_{6} \mathrm{O}_{24}$ rings (Figures 4 and 5).

Table 4 contains data on the distribution of $\mathrm{Na}$ atoms at the M2-key site in the structurally studied ${ }^{M 2} \mathrm{Na}$-dominant EGMs, most of which were found in the Lovozero massif. The exceptions are Sample 2 (Table 4), from Ilímaussaq, Greenland, labyrinthite and rastsvetaevite (Samples 20 and 21 in Table 4, respectively) which originate from the Khibiny massif and two hydrated samples from the Inagli massif, Eastern Siberia (Samples 5 and 6 in Table 4). It is to be noted that Lovozero is characterized by manganese specificity and differs from the Khibiny massif in its significantly lower iron content.

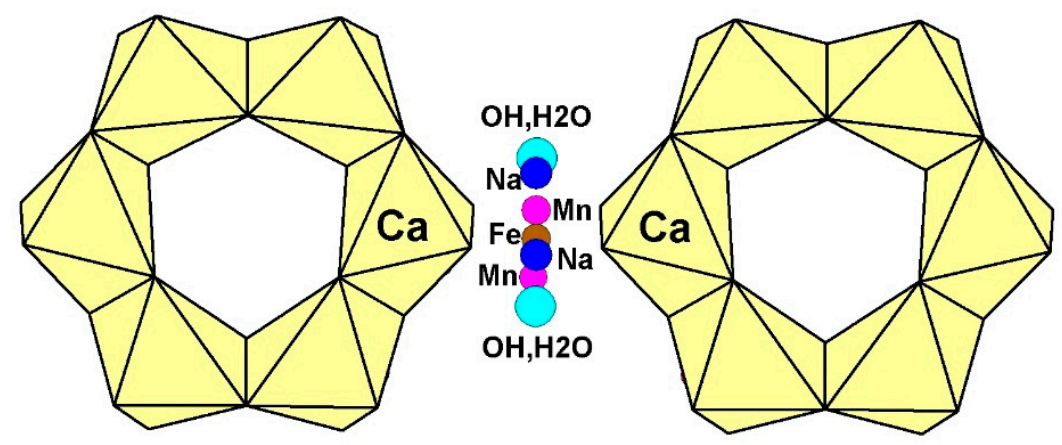

Figure 4. Cation distribution over $\mathrm{M} 2$ sites between $\mathrm{CaO}_{6}$ octahedra in Sample 4 (Table 4) [29].
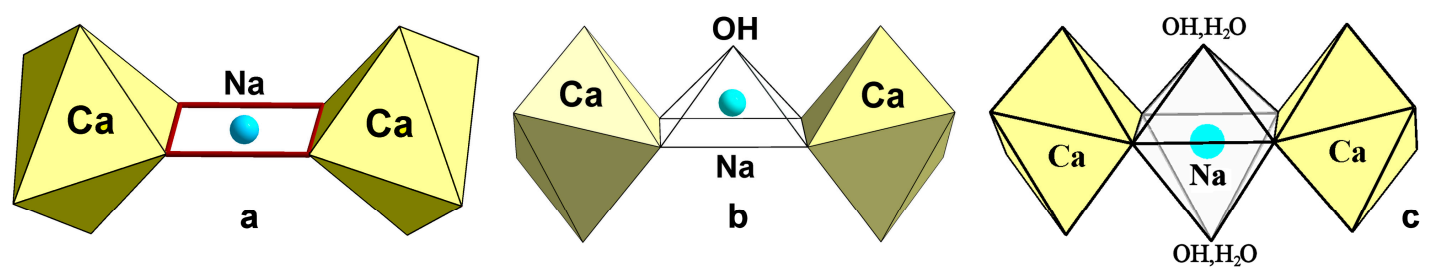

Figure 5. Na-centered coordination polyhedra in the structures of eudialyte-group minerals: square (a), tetragonal pyramid (b) and octahedron (c). 
The $M 2$ site can be split into two or more subsites. Usually, the $M 2 \mathrm{O}_{4}$ square (Figures $5 \mathrm{a}$ and 6 ) is filled with $\mathrm{Fe}^{2+}$; less often, it contains $\mathrm{Na}$. $\mathrm{Zr}, \mathrm{Hf}$ and Ta may also be present as subordinate and impurity components in this position. The four-fold coordination of ${ }^{\mathrm{M} 2} \mathrm{Na}$ is a specific feature of alluaivite [44].

The $M 2$ semioctahedron or square pyramid is a pentahedron formed on the basis of a square with the addition of an $\mathrm{OH}$-group belonging to the $\mathrm{M} 3$ or $\mathrm{M} 4$ octahedron (Figures $5 \mathrm{~b}$ and 7 ). This polyhedron can be occupied by $\mathrm{Na}^{+}, \mathrm{Fe}^{2+}, \mathrm{Fe}^{3+}$, or $\mathrm{Mn}^{2+}$.

The $M 2$ octahedron is formed when the square coordination is supplemented by the two $\mathrm{OH}$ groups of the axial $M 3$ and M4 octahedra, or by water molecules (Figures $5 \mathrm{c}$ and 8). Besides $\mathrm{Na}^{+}$, the cations $\mathrm{Fe}^{2+}, \mathrm{Fe}^{3+}$ and $\mathrm{Mn}^{2+}$ may enter the $\mathrm{M} 2$ octahedron.

The largest seven-fold $M 2$ polyhedra are built on the basis of the square involving $\mathrm{O}$ atoms of the framework (Figure 9), additional anions and/or water molecules occurring on the threefold axis. Such coordination is known for ${ }^{M 2} \mathrm{Na}^{+},{ }^{M 2} \mathrm{Mn}^{2+}$ and ${ }^{M 2} \mathrm{Zr}^{4+} .{ }^{M 2} \mathrm{NaO}_{7}$ polyhedra are dominant in the structures described in $[32,34]$. As subordinate components, such polyhedra (with the $\mathrm{Na}-\mathrm{O}$ distances in the ranges of 2.23(4)-2.96(3) and 2.33(1)-3.01(1) $\AA$ ) occur in the structures of intermediate members of the manganoeudialyte-ilyukhinite [25] and eudialyte-sergevanite [27] series, respectively.

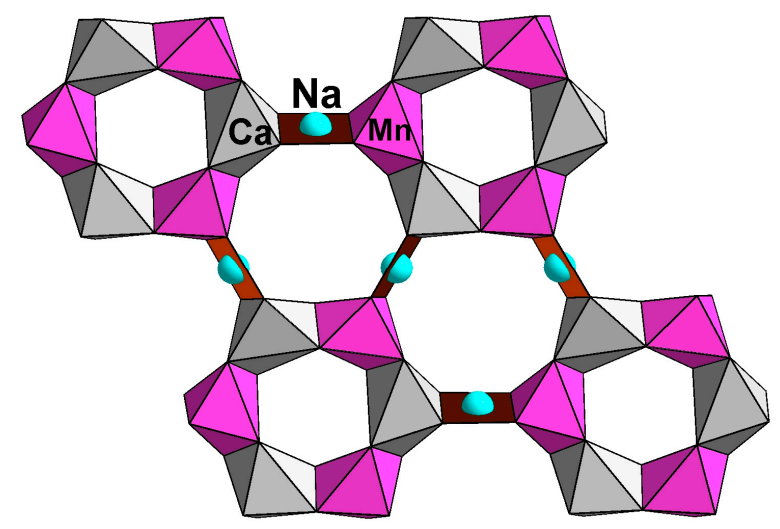

Figure 6. Combination of the rings of $\mathrm{Ca}$ - and Mn-centered octahedra via Na atoms having flat square coordination in the structure of Sample 10 (Table 4) [30].

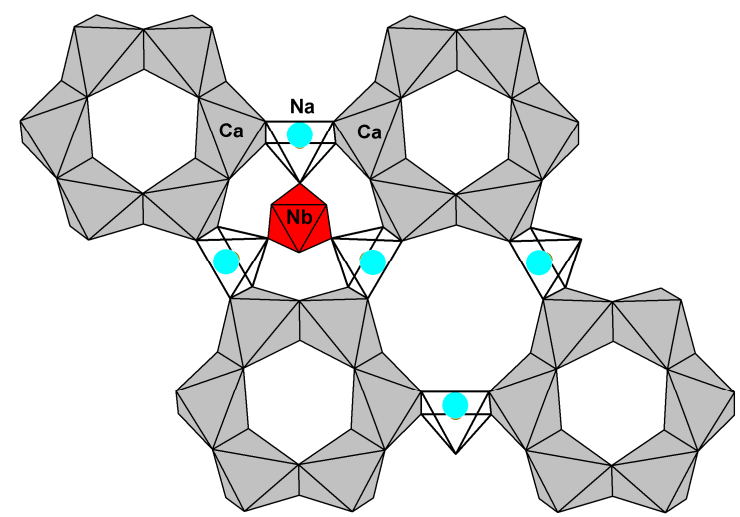

Figure 7. The local situation around ${ }^{M 2} \mathrm{Na}$-centered semioctahedra (square pyramids) in the structure of Sample 9 (Table 4) [2].

The diagnostic signs of ${ }^{M 2} \mathrm{Na}$-EGMs are the specific features of their chemical composition (low total content of $\mathrm{Fe}+\mathrm{Mn}+\mathrm{Ca}$, i.e., usually less than 7 atoms per formula unit, $\mathrm{Z}=3$, at relatively high $\mathrm{Si}$ contents) and reduced intensities of the IR bands in the range $515-545 \mathrm{~cm}^{-1}$, corresponding to ${ }^{M 2} \mathrm{Fe}-\mathrm{O}$ and ${ }^{M 2} \mathrm{Mn}-\mathrm{O}$ stretching vibrations. Until recently, these minerals were known exclusively in hyperagpaitic igneous rocks and pegmatites of the Lovozero alkaline massif, which are indicated by highly alkaline titano-, zircono- and niobo- silicates (with atomic ratios $\mathrm{Na}: \mathrm{Si} \geq 1$ ) 
such as lomonosovite, vuonnemite, zirsinalite, kazakovite, etc. [55]. Unlike the neighboring Khibiny alkaline massif, where even high-sodium EGMs typically do not contain ${ }^{M 2} \mathrm{Na}$ and mainly occur in pegmatites, in the Lovozero complex, these minerals are common components of specific igneous rocks (hyperagpaitic varieties of foyaite), and are often ${ }^{M 2} \mathrm{Na}$-dominant.

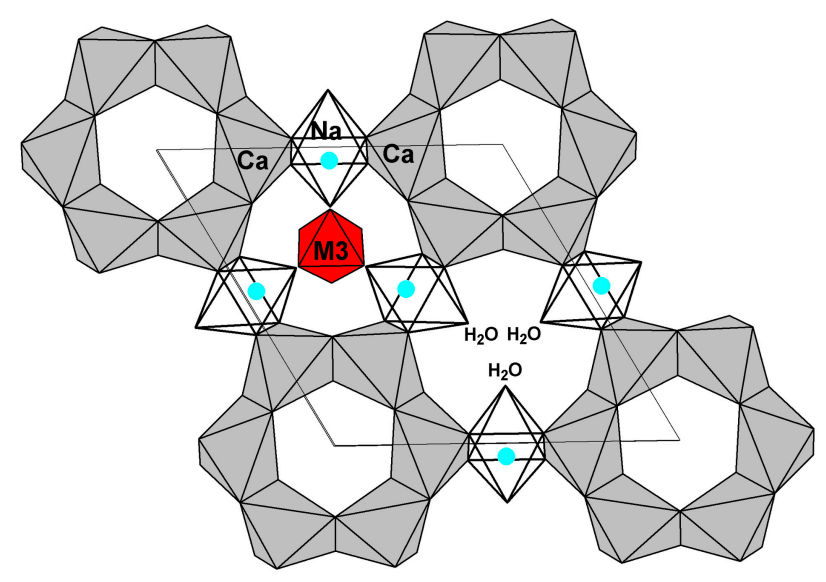

Figure 8. M2-centered octahedra in Sample 4 (Table 4) [29].

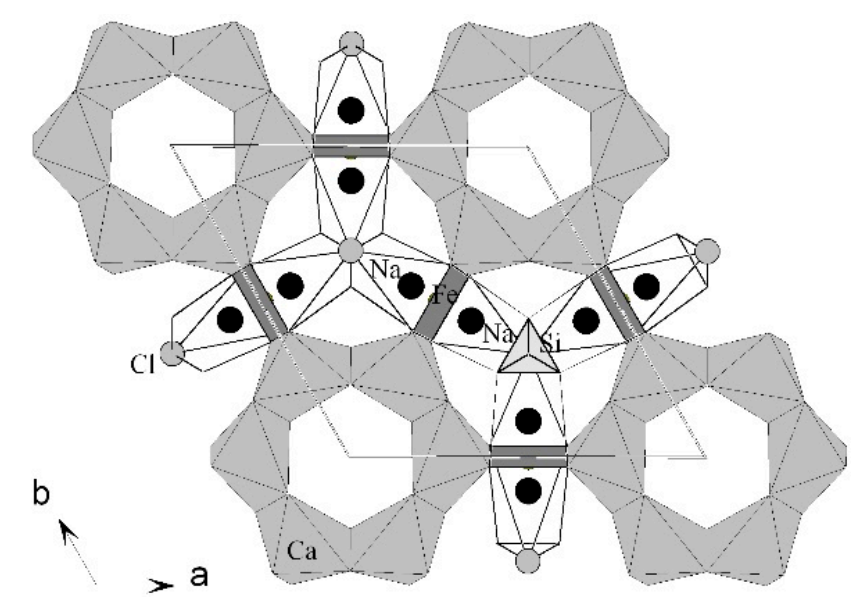

Figure 9. Seven-vertex M2 polyhedra in Sample 3 (Table 4) [32].

${ }^{M 2} \mathrm{Na}-\mathrm{EGMs}$ belong to three structure types: eudialyte (with disordered population of the M1 octahedra, space groups $R 3 m$ or $R-3 m$ ), raslakite (with ordering of $\mathrm{Ca}$ and smaller cations, $\mathrm{Fe}^{2+}$ in raslakite and $\mathrm{Mn}^{2+}$ in sergevanite; space group $R 3$ ) and alluaivite (EGMs with doubled $c$ parameter including alluaivite, dualite, rastsvetaevite and labyrinthite). ${ }^{M 2}$ Na-EGMs 1, 3 and 7 in Table 4 belong to the eudialyte structure type and are Fe-deficient, with a strong predominance of Na over Fe at $M 2$. Consequently, these samples can be considered as representatives of a potentially new mineral species.

In the structure of the Mn-rich alluaivite-type Sample 22 (Table 4 ), ${ }^{M 2} \mathrm{Na}$-dominant modules alternate with kentbrooksite (Figure 10). In rastsvetaevite (Figure 11), labyrinthite and a centrosymmetric analogue of labyrinthite (Samples 21, 20 and 23 in Table 4, respectively) ${ }^{M 2} \mathrm{Na}$-dominant modules alternate with eudialyte. The alternation of modules with different populations at the $M 2$ site is one of the main causes of the unit-cell doubling in these minerals. 


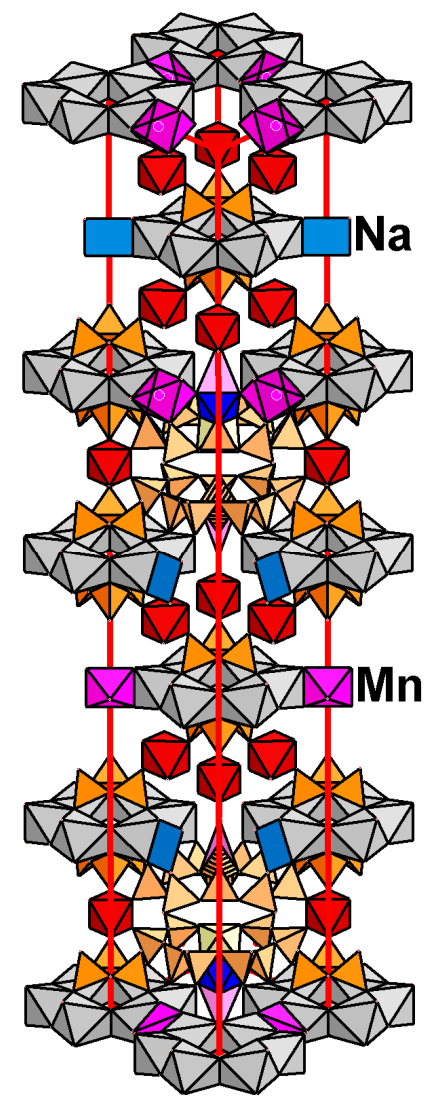

Figure 10. Alternation of Na- and Mn-centered square pyramids in the Mn-rich, alluaivite-type Sample 22 (Table 4) [51].

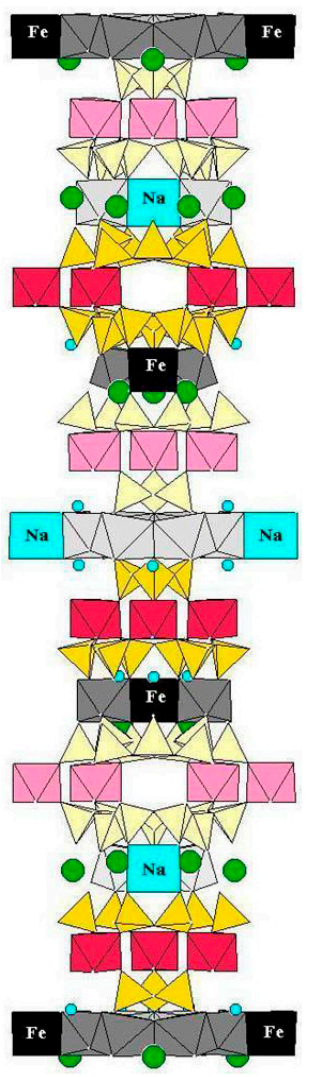

Figure 11. Alternation of $\mathrm{Na}$ - and Fe-centered squares in rastsvetaevite $[49,50]$. 
Author Contributions: R.K.R., N.V.C. and I.V.P. wrote the paper. N.V.C. obtained and interpreted the IR spectra. K.V.V. obtained chemical data. R.K.R. carried out the crystal-chemical analysis. I.V.P. and C.S. provided Samples 1 and 2, respectively. All authors have read and agreed to the published version of the manuscript.

Funding: This work was supported by the Ministry of Science and Higher Education within the State assignment FSRC «Crystallography and Photonics» RAS and state task, state registration number AAAA-A19-119092390076-7 (X-ray crystal structure analysis) and Russian Science Foundation, projects nos. 18-29-12005 (crystal-chemical analysis) and 18-29-12007 (IR spectroscopy and electron microprobe analyses).

Conflicts of Interest: The authors declare no conflict of interest.

\section{References}

1. Sjöqvist, A.S.L. The tale of greenlandite: Commemorating the two-hundredth anniversary of eudialyte (1819-2019). Minerals 2019, 9, 497. [CrossRef]

2. Rastsvetaeva, R.K.; Chukanov, N.V.; Aksenov, S.M. Minerals of Eudialyte Group: Crystal Chemistry, Properties, Genesis; University of Nizhni Novgorod: Nizhniy Novgorod, Russia, 2012; p. 230, ISBN 978-5-91326-207-3. (In Russian)

3. Johnsen, O.; Grice, J.D.; Gault, R.A. The crystal chemistry of the eudialyte group. Canad. Mineral. 1999, 37, 865-891.

4. Johnsen, O.; Ferraris, G.; Gault, R.A.; Grice, J.D.; Kampf, A.R.; Pekov, I.V. The nomenclature of eudialyte group minerals. Canad. Mineral. 2003, 41, 785-794. [CrossRef]

5. Rastsvetaeva, R.K.; Khomyakov, A.P. Crystal chemistry of modular eudialytes. Crystallogr. Rep. 2003, 48, S78-S90.

6. Rastsvetaeva, R.K. Structure mineralogy of eudialyte group. Crystallogr. Rep. 2007, 52, 50-67. [CrossRef]

7. Rastsvetaeva, R.K.; Chukanov, N.V. Classification of eudialyte-group minerals. Geol. Ore Depos. 2012, 54, 487-497. [CrossRef]

8. Rastsvetaeva, R.K.; Chukanov, N.V.; Aksenov, S.M. Crystalchemical principles of classifying the Eudialyte group. In Proceedings of the 35th International Geological Congress, Cape Town, South Africa, 27 August4 September 2016; p. 4193.

9. Rastsvetaeva, R.K.; Aksenov, S.M.; Rozenberg, K.A. Crystal structure and genesis of hydrated analog of rastsvetaevite. Crystallogr. Rep. 2015, 60, 897-905. [CrossRef]

10. Rozenberg, K.A.; Rastsvetaeva, R.K.; Aksenov, S.M. Crystal structure of modular sodium-rich and low-iron eudialyte from Lovozero alkaline massif. Crystallogr. Rep. 2016, 61, 779-785. [CrossRef]

11. Rastsvetaeva, R.K.; Rozenberg, K.A.; Chukanov, N.V.; Aksenov, S.M. Crystal structure of ilyukhinite, a new mineral of the eudialyte group. Crystallogr. Rep. 2017, 62, 60-65. [CrossRef]

12. Chukanov, N.V.; Rastsvetaeva, R.K.; Rozenberg, K.A.; Aksenov, S.M.; Pekov, I.V.; Belakovsky, D.I.; Kristiansen, R.; Van, K.V. Ilyukhinite, $\left(\mathrm{H}_{3} \mathrm{O}, \mathrm{Na}\right)_{14} \mathrm{Ca}_{6} \mathrm{Mn}_{2} \mathrm{Zr}_{3} \mathrm{Si}_{26} \mathrm{O}_{72}(\mathrm{OH})_{2} \cdot 3 \mathrm{H}_{2} \mathrm{O}$, a new mineral of the eudialyte group. Geol. Ore Depos. 2017, 59, 592-600. [CrossRef]

13. Rastsvetaeva, R.K.; Rozenberg, K.A.; Aksenov, S.M. Modular structure of highly ordered eudialyte and its place among hydrated minerals of rastsvetaevite family. Crystallogr. Rep. 2017, 62, 551-557. [CrossRef]

14. Zaitsev, V.A.; Aksenov, S.M.; Rastsvetaeva, R.K.; Chukanov, N.V. Sr-rich eudialyte group mineral (Cl-deficient analogue of taseqite) from the Odikhincha Massif, Polar Siberia, Russia. In Proceedings of the XXXIV International Conference "Magmatism of the Earth and related strategic metal deposits", Miass, Russia, 4-9 August 2017; pp. 319-321.

15. Aksenov, S.M.; Zaitsev, V.A.; Rastsvetaeva, R.K.; Chukanov, N.V. Crystal Structure Features of Cl-Deficient Analogue of Taseqite from the Odichincha Massif (Russia); Abstracts of XII L.L; Perchuk International School of Earth Sciences (I.S.E.S.-2017); Institute of Mineralogy of the Ural Branch of the Russian Academy of Science: Miass, Russia, 2017; Volume 7.

16. Rastsvetaeva, R.K.; Chukanov, N.V.; Zaitsev, B.A.; Aksenov, S.M.; Viktorova, K.A. Crystal structure of Cl-deficiente analog of tasekite from the Odihincha massif. Crystallogr. Rep. 2018, 63, 392-400. [CrossRef]

17. Rastsvetaeva, R.K.; Chukanov, N.V.; Viktorova, K.A.; Aksenov, S.M. New data on the Isomorphism in eudialyte-group minerals. I. Crystal structure of titanium-rich eudialyte from the Kovdor alkaline massif. Crystallogr. Rep. 2018, 63, 563-569. [CrossRef]

18. Rastsvetaeva, R.K.; Viktorova, K.A.; Aksenov, S.M. New data on the Isomorphism in Eudialyte-Group Minerals. II. Refinement of the aqualite crystal structure at 110 K. Crystallogr. Rep. 2018, 63, 884-889. [CrossRef] 
19. Chukanov, N.V.; Rastsvetaeva, R.K.; Kruszewski, Ł.; Aksenov, S.M.; Rusakov, V.S.; Britvin, S.N.; Vozchikova, S.A. Siudaite, $\mathrm{Na}_{8}\left(\mathrm{Mn}^{2+}{ }_{2} \mathrm{Na}\right) \mathrm{Ca}_{6} \mathrm{Fe}^{3+}{ }_{3} \mathrm{Zr}_{3} \mathrm{NbSi}_{25} \mathrm{O}_{74}(\mathrm{OH})_{2} \mathrm{Cl} \cdot 5 \mathrm{H}_{2} \mathrm{O}$, a new eudialyte-group mineral from the Khibiny alkaline massif, Kola Peninsula. Phys. Chem. Min. 2018, 45, 745-758. [CrossRef]

20. Rastsvetaeva, R.K.; Viktorova, K.A.; Aksenov, S.M. New Data on the Isomorphism in Eudialyte-Group Minerals. III. Modular structure of K-analog of centrosymmetrical labyrinthite. Crystallogr. Rep. 2019, 64, 203-208. [CrossRef]

21. Rastsvetaeva, R.K.; Viktorova, K.A.; Aksenov, S.M. New data on the isomorphism in eudialyte-group minerals. IV. Modular structure of titanosilicate with replacement of $\mathrm{Na}$ by $\mathrm{Mn}$ in the alluaivite module. Crystallogr. Rep. 2019, 64, 561-564. [CrossRef]

22. Rastsvetaeva, R.K.; Aksenov, S.M.; Chukanov, N.V. New data on crystal chemistry of eudialyte-group minerals. In Proceedings of the XIX International Meeting on Crystal Chemistry, X-ray Diffraction and Spectroscopy of Minerals, Apatity, Russia, 2-8 July 2019. Book of Abstracts, 81.

23. Rastsvetaeva, R.K.; Aksenov, S.M.; Chukanov, N.V. New data on the crystal chemistry and systematics of minerals of eudialyte group. Cryst. Probl. 2019, 7, 192-202. (In Russian)

24. Rastsvetaeva, R.K.; Chukanov, N.V.; Pekov, I.V.; Varlamov, D.A. Structural features of potential new mineral of eudialyte group from the Lovozero massif, Kola peninsula. Vestn. Geosci. 2020, 1, 3-7. [CrossRef]

25. Rastsvetaeva, R.K.; Chukanov, N.V.; Möckel, S.; Dudka, A.P.; Aksenov, S.M. New data on the isomorphism in eudialyte-group minerals. V. Crystal structure of an intermediate member of the manganoeudialyteilyukhinite isomorphous Series. Crystallogr. Rep. 2020, 65, 32-37. [CrossRef]

26. Rastsvetaeva, R.K.; Chukanov, N.V.; Pekov, I.V.; Varlamov, D.A.; Aksenov, S.M. New data on the isomorphism in eudialyte-group minerals. VI. Crystal structure of the first member containing sulfide anion with isomorphic substitution $\mathrm{Cl}^{-}-\mathrm{S}^{2-}$. Crystallogr. Rep. 2020, 65, 215-222. [CrossRef]

27. Rastsvetaeva, R.K.; Chukanov, N.V.; Van, K.V. New Data on the isomorphism in eudialyte-group minerals. VII. Crystal structure of the eudialyte-sergevanite mineral series from the Lovozero alkaline massif. Crystallogr. Rep. 2020, 65, 555-561. [CrossRef]

28. Rastsvetaeva, R.K.; Chukanov, N.V.; Sipavina, L.V.; Voronin, M.V. New data on the isomorphism in eudialyte-group minerals. VIII. Crystal structure of $\mathrm{Fe}^{2+}$-analog of $\mathrm{Fe}^{2+}$-analog feklichevite-potentionally new mineral from the Khibiny massif. Crystallogr. Rep. 2020, 65. in press.

29. Rastsvetaeva, R.K.; Chukanov, N.V.; Lisitsin, D.V. New data on the isomorphism in eudialyte-group minerals. IX. Block isomorphism in key sites. Crystal structure of a Fe-deficient eudialyte from the Khibiny Massif. Crystallogr. Rep. 2020, 65. in press. [CrossRef]

30. Rastsvetaeva, R.K.; Chukanov, N.V. New data on the isomorphism in eudialyte-group minerals. X. Specific features of isomorphism in the raslakite-sergevanite solid-solution series. Crystal structure of an intermediate member. Crystallogr. Rep. 2021, 66. in press.

31. Rastsvetaeva, R.K.; Chukanov, N.V. Crystal Chemistry of Na-Dominant (at the M2 Site) Eudialyte Group Minerals as Indicators of Hyperalkaline Formations. Russian Conference with International Participation «Modern Problems of Theoretical, Experimental and Applied Mineralogy» (Yuschkinskie Reports-2020); 2020; in press.

32. Rozenberg, K.A.; Rastsvetaeva, R.K.; Verin, I.A. Crystal structure of centrosymmetrical 12-layer high sodium eudialyte. Crystallogr. Rep. 2009, 54, 446-450. [CrossRef]

33. Rozenberg, K.A.; Rastsvetaeva, R.K.; Khomyakov, A.P. Decationized and hydrated eudialytes. Oxonium problem. Eur. J. Mineral. 2005, 17, 875-882. [CrossRef]

34. Rastsvetaeva, R.K.; Khomyakov, A.P. The crystal structure of the low-iron analogue of eudialyte. Doklady Akademii Nauk 1998, 362, 784-788.

35. Rastsvetaeva, R.K.; Karipidis, T.K. Cationic ordering in the structure of titanium-rich eudialytes. In Proceedings of the 11th international conference "Order-Disorder in Minerals and alloys (OMA)", Rostov-on-Don, Russia, 30 September-8 October 2008; Part II. pp. 138-141. (In Russian)

36. Ekimenkova, I.A.; Rastsvetaeva, R.K.; Chukanov, N.V. Ordering of calcium and iron in a mineral of the eudialyte group with the symmetry R3. Doklady Chem. 2000, 374, 195-198.

37. Chukanov, N.V.; Pekov, I.V.; Zadov, A.E.; Korovushkin, V.V.; Ekimenkova, I.A.; Rastsvetaeva, R.K. Ikranite $\left(\mathrm{Na}, \mathrm{H}_{3} \mathrm{O}\right)_{15}(\mathrm{Ca}, \mathrm{Mn}, \mathrm{REE})_{6} \mathrm{Fe}^{3+}{ }_{2} \mathrm{Zr}_{3}(\square, \mathrm{Zr})(\square, \mathrm{Si}) \mathrm{Si}_{24} \mathrm{O}_{66}(\mathrm{O}, \mathrm{OH})_{6} \mathrm{Cl} \cdot n \mathrm{H}_{2} \mathrm{O}$ and raslakite $\mathrm{Na}_{15} \mathrm{Ca}_{3} \mathrm{Fe}_{3}(\mathrm{Na}, \mathrm{Zr})_{3}$ $\mathrm{Zr}_{3}(\mathrm{Si}, \mathrm{Nb})\left(\mathrm{Si}_{25} \mathrm{O}_{73}\right)\left(\mathrm{OH}, \mathrm{H}_{2} \mathrm{O}\right)_{3}(\mathrm{Cl}, \mathrm{OH})$-new minerals of the eudialyte-group from Lovozero massif. Geol. Ore Depos. 2003, 5, 22-33. 
38. Rastsvetaeva, R.K.; Aksenov, S.M.; Chukanov, N.V. Crystal structure of the Mn analogue of raslakite, a new representative of the eudialyte group. Doklady Chem. 2010, 431, 76-81. [CrossRef]

39. Rastsvetaeva, R.K.; Khomyakov, A.P. Crystal structure features of Na,Fe-decationized eudialyte with R3 symmetry. Crystallogr. Rep. 2002, 47, 267-271. [CrossRef]

40. Khomyakov, A.P.; Nechelyustov, G.N.; Rastsvetaeva, R.K. Aqualite $\left(\mathrm{H}_{3} \mathrm{O}\right)_{8}(\mathrm{Na}, \mathrm{K}, \mathrm{Sr})_{5} \mathrm{Ca}_{6} \mathrm{Zr}_{3} \mathrm{Si}_{26} \mathrm{O}_{66}(\mathrm{OH})_{9} \mathrm{Cl}-$ A new mineral of eudialyte-group from the alkaline Inagli massif, Saha-Yakutiya, Russia, and oxonium problem in hydrated eudialytes. Geol. Ore Depos. 2007, 136, 39-55.

41. Rastsvetaeva, R.K.; Khomyakov, A.P.; Nekrasov, Y.V. Crystal structure of a new eudialyte analog with R3 symmetry. Crystallogr. Rep. 1999, 44, 824-828.

42. Rastsvetaeva, R.K.; Khomyakov, A.P. Crystal structure of hyperzirconium analog of eudialyte. Crystallogr. Rep. 2000, 45, 251-253. [CrossRef]

43. Aksenov, S.M.; Rastsvetaeva, R.K. Refinement of the crystal structure of hyperzirconium eudialyte and its place among low calcium minerals of the eudialyte-group. Crystallogr. Rep. 2013, 58, 555-561. [CrossRef]

44. Rastsvetaeva, R.K.; Khomyakov, A.P.; Andrianov, V.I.; Gusev, A.I. Crystal structure of allyaivite. Doklady Akademii Nauk SSSR 1990, 312, 1379-1383. (In Russian)

45. Rastsvetaeva, R.K.; Khomyakov, A.P.; Chapuis, G. Crystal structure and crystal-chemical features of a new Ti-rich member of the eudialyte family. Z. Krist. 1999, 214, 271-278. [CrossRef]

46. Khomyakov, A.P.; Nechelyustov, G.N.; Rastsvetaeva, R.K. Dualite $\mathrm{Na}_{30}(\mathrm{Ca}, \mathrm{Na}, \mathrm{Ce}, \mathrm{Sr})_{12}(\mathrm{Na}, \mathrm{Mn}, \mathrm{Fe}, \mathrm{Ti})_{6}$ $\mathrm{Zr}_{3} \mathrm{Ti}_{3} \mathrm{Si}_{51} \mathrm{O}_{144}\left(\mathrm{OH}, \mathrm{H}_{2} \mathrm{OCl}\right)_{9}-\mathrm{A}$ new zircono-titanium silicate with modular eudialyte like structure from the Lovozero alkaline massif, Kola peninsula, Russia. Geol. Ore Depos. 2007, 4, 31-42.

47. Rastsvetaeva, R.K.; Khomyakov, A.P. Modular structure of high sodium eudialyte analog with doubled c-period and R3 symmetry. Crystallogr. Rep. 2001, 46, 827-832.

48. Khomyakov, A.P.; Nechelyustov, G.N.; Rastsvetaeva, R.K. Labyrinthite (Na,K,Sr) ${ }_{35} \mathrm{Ca}_{12} \mathrm{Fe}_{3} \mathrm{Zr}_{6} \mathrm{TiSi}_{51} \mathrm{O}_{144}$ $\left(\mathrm{O}, \mathrm{OH}, \mathrm{H}_{2} \mathrm{O}\right)_{9} \mathrm{Cl}_{3}-\mathrm{A}$ new mineral with modular eudialyte-like structure from the Khibiny alkaline massif, Kola peninsula, Russia. Geol. Ore Depos. 2006, 2, 38-49.

49. Khomyakov, A.P.; Nechelyustov, G.N.; Arakcheeva, A.V. Rastsvetaevite $\mathrm{Na}_{27} \mathrm{~K}_{8} \mathrm{Ca}_{12} \mathrm{Fe}_{3} \mathrm{Zr}_{6} \mathrm{Si}_{4}\left[\mathrm{Si}_{3} \mathrm{O}_{9}\right]_{4}$ $\left[\mathrm{Si}_{9} \mathrm{O}_{27}\right]_{4}\left(\mathrm{O}, \mathrm{OH}, \mathrm{H}_{2} \mathrm{O}\right)_{6} \mathrm{Cl}_{2}-\mathrm{A}$ new mineral with modular eudialyte-like structure and crystal-chemical systematics of eudialyte group. Geol. Ore Depos. 2006, 1, 49-65.

50. Rastsvetaeva, R.K.; Khomyakov, A.P. Modular structure of a high-potassium analog of eudialyte with a doubled period c. Crystallogr. Rep. 2001, 46, 715-721.

51. Rastsvetaeva, R.K.; Ivanova, A.G.; Khomyakov, A.P. Modular structure of hypermanganese eudialyte. Doklady Earth Sci. 2006, 410, 1075-1079. [CrossRef]

52. Golyshev, V.M.; Simonov, B.I.; Belov, N.B. On the crystal structure of eudialyte. Kristallografiya 1971, 16, 93-98. (In Russian)

53. Golyshev, V.M.; Simonov, B.I.; Belov, N.B. The crystal structure of eudialyte. Kristallografiya 1972, 17, 1119-1123. (In Russian)

54. Giuseppetti, G.; Mazzi, F.; Tadini, C. The crystal structure of eudialyte. Tschermaks Mineral. Petrogr. Mitt. 1971, 16, 105-127. [CrossRef]

55. Khomyakov, A.P. Mineralogy of Ultra-Agpaitic Alkaline Rocks; Nauka: Moscow, Russia, 1990; 196p.

(C) 2020 by the authors. Licensee MDPI, Basel, Switzerland. This article is an open access article distributed under the terms and conditions of the Creative Commons Attribution (CC BY) license (http://creativecommons.org/licenses/by/4.0/). 